\title{
C-H Bond activation by dicationic platinum(II) complexes
}

\author{
Tom G. Driver, Travis J. Williams, Jay A. Labinger, * and John E. Bercaw* \\ Arnold and Mabel Beckman Laboratories of Chemical Synthesis \\ California Institute of Technology, Pasadena, California 91125
}

\section{Contents:}

\section{Supporting Information}

I. Examination of alternative Lewis acids.......................................................

II. Diprotonolysis of platinum dimethyl 1 with triflic acid or $\mathrm{BF}_{3} \ldots \ldots \ldots \ldots \ldots \ldots \ldots . . . . . .3-3$

III. Generality of double protonation of $\mathrm{Ar}_{2}(\mathrm{NN}) \mathrm{PtMe}_{2}$ with $\mathrm{F}_{3} \mathrm{~B} \cdot \mathrm{DOCD}_{2} \mathrm{CF}_{3}$ and reactivity of platinum dications............................................................s-7

IV. Reactivity of platinum dication 5a: observation of $\pi$-arene complexes and $\mathrm{C}-\mathrm{H}$ bond activation........................................................................ $s-8$

V. Mechanism of $\eta^{3}$-benzyl formation: kinetics and isotopic labeling................s-11

VI. Other $\mathrm{C}-\mathrm{H}$ bond activations at dicationic platinum centers...........................s-13

VII. References.................................................................................. 18

VIII. Crystallographic data of 14a................................................................... 19

General. ${ }^{1} \mathrm{H}$ NMR and ${ }^{13} \mathrm{C}$ NMR spectra were recorded at ambient temperature using Varian 600 or 300 spectrometers. The data are reported as follows: chemical shift in ppm from internal tetramethylsilane on the $\delta$ scale, multiplicity $(\mathrm{br}=$ broad, $\mathrm{s}=$ singlet, $\mathrm{d}=$ doublet, $\mathrm{t}=$ triplet, $\mathrm{q}=$ quartet, $\mathrm{m}=$ multiplet $)$, coupling constants $(\mathrm{Hz})$ and integration. Mass spectra were acquired on a Finnigan LCQ ion trap or Agilent 5973 Network Mass Selective detector, and were obtained by peak matching. All reactions were carried out under an atmosphere of nitrogen in glassware, which had been oven-dried. Unless otherwise noted, all reagents were commercially obtained and, where appropriate, purified prior to use. Tris(pentafluorophenyl)borane $\left[\mathrm{B}\left(\mathrm{C}_{6} \mathrm{~F}_{5}\right)_{3}\right]$ was purified by sublimation $\left(90{ }^{\circ} \mathrm{C}, 0.5 \mathrm{mmHg}\right)$. Trifluoroborane was purified following the procedure of Brown and coworkers: ${ }^{1}$ the borane was condensed into benzonitrile and evacuated. The borane was liberated from the resultant complex by mild heating to $60^{\circ} \mathrm{C}$. The borane was passed through two $-78{ }^{\circ} \mathrm{C}$ traps and condensed at $-196{ }^{\circ} \mathrm{C}$. It was then vacuum distilled by warming to $-78^{\circ} \mathrm{C}$. A known volume of $\mathrm{BF}_{3}$ was then condensed into trifluoroethanol to form a $0.4776 \mathrm{M}$ solution. Triflic acid (DOTf) was vacuum distilled from $\mathrm{P}_{2} \mathrm{O}_{5}$. Trifluoroethanol- $d_{3}$ was dried over $3 \AA$ molecular sieves for at least $5 \mathrm{~d}$ and then was vacuum distilled onto $\mathrm{B}\left(\mathrm{C}_{6} \mathrm{~F}_{5}\right)_{3}$. After $6 \mathrm{~h}$, the trifluoroethanol- $d_{3}$ was vacuum distilled to, and stored in a valved reaction vessel. The platinum dimethyl complexes were synthesized following earlier reported procedures. ${ }^{2}$ Ethylbenzene, 1,4diethylbenzene, and 1,3,5-triethylbenzene were vacuum distilled from $\mathrm{Na}(0)$. Benzene was vacuum distilled from sodium benzophenone. $p$-Xylene, allylbenzene, cyclohexene were vacuum distilled from $\mathrm{CaH}$. 1-Pentene was vacuum distilled from lithium aluminum hydride. Cyclohexane and $n$-pentane were vacuum distilled from sodium benzophenone. Methane was dried over alumina for 24 hours before use. Trifluoroethanol- $d_{3}$, Lewis acids, substrates, and platinum dimethyl complexes were stored in a Vacuum Atmospheres nitrogen atmosphere dry box. 

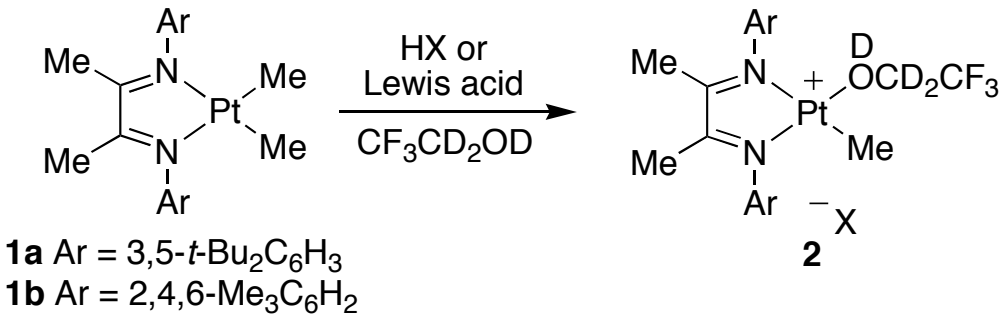

Representative formation of $\mathrm{Ar}_{2}(\mathrm{NN}) \mathrm{PtMe}^{+} \mathbf{2 a}$ from $\mathrm{Ar}_{2}(\mathrm{NN}) \mathrm{PtMe}_{2}$ 1a. To a suspension of platinum dimethyl $1 \mathrm{a}(0.010 \mathrm{~g}, 0.015 \mathrm{mmol})$ in $0.700 \mathrm{~mL}$ of $\mathrm{CF}_{3} \mathrm{CD}_{2} \mathrm{OD}$ was added acid $(0.015 \mathrm{mmol})$. The resulting purple mixture was vigorously agitated until a light orange solution was obtained. The solution was transferred to a J. Young tube and analyzed for formation of platinum methyl cation $\mathbf{2 a}$ using ${ }^{1} \mathrm{H}$ NMR spectroscopy: ${ }^{1} \mathrm{H}$ NMR (300 MHz, $\left.\mathrm{CF}_{3} \mathrm{CD}_{2} \mathrm{OD}\right) \delta 7.62(\mathrm{t}, J=1.8 \mathrm{~Hz}, 1 \mathrm{H}), 7.54(\mathrm{t}, J=1.8 \mathrm{~Hz}, 1 \mathrm{H}), 7.04(\mathrm{~d}, J=1.5 \mathrm{~Hz}, 2 \mathrm{H}), 6.85$ $(\mathrm{d}, J=1.5 \mathrm{~Hz}, 2 \mathrm{H}), 2.00(\mathrm{~s}, 3 \mathrm{H}), 1.87(\mathrm{~s}, 3 \mathrm{H}), 1.37(\mathrm{~s}, 18 \mathrm{H}), 1.36(\mathrm{~s}, 18 \mathrm{H}), 0.74\left(\mathrm{Pt}-\mathrm{CH}_{3}, \mathrm{~s}, 3 \mathrm{H}, J_{\mathrm{Pt}-\mathrm{H}}=63.0\right.$ $\mathrm{Hz}), 0.73\left(\mathrm{Pt}-\mathrm{CDH}_{2}, \mathrm{~s}\right)$. The ${ }^{1} \mathrm{H}$ NMR data matched that reported by Zhong, Labinger, and Bercaw. ${ }^{3}$

$\mathbf{A r}_{2}(\mathbf{N N}) \mathbf{P t M e}^{+} \mathbf{2 b}$. To a suspension of platinum dimethyl $\mathbf{1 b}(0.0080 \mathrm{~g}, 0.015 \mathrm{mmol})$ in $0.700 \mathrm{~mL}$ of $\mathrm{CF}_{3} \mathrm{CD}_{2} \mathrm{OD}$ was added acid $(0.015 \mathrm{mmol})$. The resulting purple mixture was vigorously agitated until a light orange solution was obtained. The solution was transferred to a J. Young tube and analyzed for formation of platinum methyl cation 2b using ${ }^{1} \mathrm{H}$ NMR spectroscopy: ${ }^{1} \mathrm{H}$ NMR $\left(300 \mathrm{MHz}, \mathrm{CF}_{3} \mathrm{CD}_{2} \mathrm{OD}\right) \delta 7.12$ (s, $\left.2 \mathrm{H}\right), 7.06$ $(\mathrm{s}, 2 \mathrm{H}), 2.34(\mathrm{~s}, 3 \mathrm{H}), 2.33(\mathrm{~s}, 3 \mathrm{H}), 2.84(\mathrm{~s}, 6 \mathrm{H}), 2.15(\mathrm{~s}, 6 \mathrm{H}), 1.90(\mathrm{~s}, 3 \mathrm{H}), 1.74(\mathrm{~s}, 3 \mathrm{H}), 0.65\left(\mathrm{Pt}-\mathrm{CH}_{3}, \mathrm{~s}, 3 \mathrm{H}, J_{\mathrm{Pt}-}\right.$ $\mathrm{H}=69.0 \mathrm{~Hz}), 0.63\left(\mathrm{Pt}-\mathrm{CDH}_{2}, \mathrm{~s}\right)$. The ${ }^{1} \mathrm{H}$ NMR data matched that reported by Zhong, Labinger, and Bercaw. ${ }^{3}$

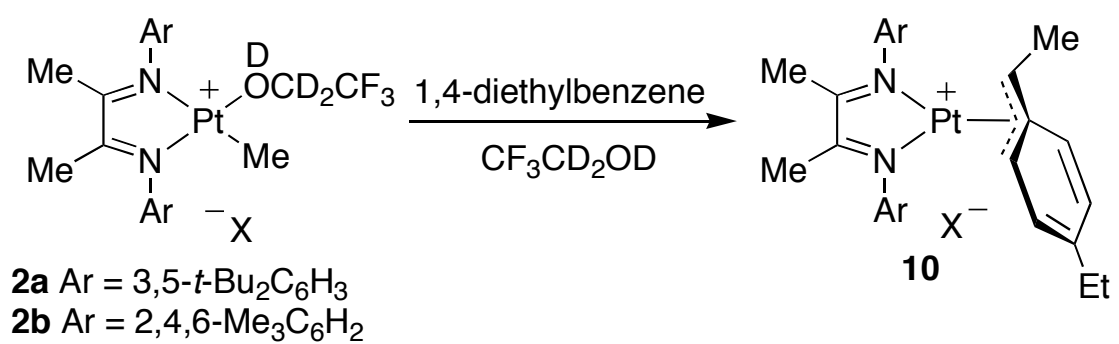

Representative formation of $\boldsymbol{\eta}^{3}$-benzyl complex 10 a from $\operatorname{Ar}_{2}(\mathbf{N N}) \mathrm{PtMe}^{+} \mathbf{2 a}$. To a light orange solution of platinum methyl cation $2 \mathrm{a}(0.015 \mathrm{mmol})$ in $0.700 \mathrm{~mL}$ of trifluoroethanol- $d_{3}$ was added $0.025 \mathrm{~mL}$ of $1,4-$ diethylbenzene $(0.16 \mathrm{mmol})$. The progress of the reaction was monitored periodically using ${ }^{1} \mathrm{H}$ NMR spectroscopy. After $15 \mathrm{~h},{ }^{1} \mathrm{H}$ NMR spectroscopy analysis revealed complete consumption of $\mathbf{2 a}$ and formation of $\eta^{3}$-product 10a (in situ characterization data): ${ }^{1} \mathrm{H}$ NMR $\left(300 \mathrm{MHz}, \mathrm{CF}_{3} \mathrm{CD}_{2} \mathrm{OD}\right) \delta 7.61(\mathrm{~s}, 1 \mathrm{H}), 7.59(\mathrm{~s}, 1 \mathrm{H})$, 7.24 (br s, 1H), 7.45 (s, 1H), 6.96 (br s, 2H), 6.80 (br s, 1H), 6.47 (s, 1H), $6.39(\mathrm{~s}, 1 \mathrm{H}), 5.88(\mathrm{~d}, J=6.6 \mathrm{~Hz}, 1 \mathrm{H})$, $2.82(\mathrm{q}, J=6.6 \mathrm{~Hz}, 1 \mathrm{H}), 2.08(\mathrm{dd}, J=14.7,7.5 \mathrm{~Hz}, 1 \mathrm{H}), 2.02(\mathrm{~s}, 3 \mathrm{H}), 2.00(\mathrm{dd}, J=14.7,7.5 \mathrm{~Hz}, 1 \mathrm{H}), 1.93(\mathrm{~s}$, $3 \mathrm{H}), 1.44$ (s, 9H), 1.39 (br s, 9H), 1.36 (br s, 9H), 1.30 (s, 9H), 0.93 (t, J=7.5 Hz, 3H), 0.29 (d, J=6.6 Hz, 3H). The ${ }^{1} \mathrm{H}$ NMR data matched that reported by Driver, Heyduk, Labinger, and Bercaw. ${ }^{4,5}$

$\eta^{3}$-Benzyl complex 10b. To a light orange solution of platinum methyl cation $\mathbf{2 a}(0.015 \mathrm{mmol})$ in $0.700 \mathrm{~mL}$ of trifluoroethanol- $d_{3}$ was added $0.025 \mathrm{~mL}$ of 1,4 -diethylbenzene $(0.16 \mathrm{mmol})$. The progress of the reaction was monitored periodically using ${ }^{1} \mathrm{H}$ NMR spectroscopy. After $15 \mathrm{~h}$, the reaction mixture was cooled and ${ }^{1} \mathrm{H}$ NMR spectroscopy analysis revealed complete consumption of $\mathbf{2 a}$ and formation of $\eta^{3}$-product 10a (in situ characterization data): ${ }^{1} \mathrm{H}$ NMR $\left(300 \mathrm{MHz}, \mathrm{CF}_{3} \mathrm{CD}_{2} \mathrm{OD}\right) \delta 7.13(\mathrm{~s}, 1 \mathrm{H}), 7.12(\mathrm{~s}, 1 \mathrm{H}), 7.06(\mathrm{~s}, 1 \mathrm{H}), 6.96(\mathrm{AB}$ 
splitting, 1H), $6.91(\mathrm{~s}, 1 \mathrm{H}), 6.05(\mathrm{~s}, 1 \mathrm{H}), 6.05(\mathrm{~d}, J=5.8 \mathrm{~Hz}, 1 \mathrm{H}), 5.62\left(\mathrm{~d}, J=6.0 \mathrm{~Hz}, J_{\mathrm{PtH}}=23 \mathrm{~Hz}, 1 \mathrm{H}\right), 2.76$ $\left(\mathrm{q}, J=6.6 \mathrm{~Hz}, J_{\mathrm{PtH}}=33 \mathrm{~Hz}, 1 \mathrm{H}\right), 2.37(\mathrm{~s}, 3 \mathrm{H}), 2.34(\mathrm{~s}, 6 \mathrm{H}), 2.18(\mathrm{~s}, 3 \mathrm{H}), 2.16(\mathrm{~m}, 1 \mathrm{H}), 2.07(\mathrm{~m}, 1 \mathrm{H}), 1.96(\mathrm{~s}$, $3 \mathrm{H}), 1.89(\mathrm{~s}, 3 \mathrm{H}), 1.85(\mathrm{~s}, 3 \mathrm{H}), 1.46(\mathrm{~s}, 3 \mathrm{H}), 1.03(\mathrm{t}, J=7.2 \mathrm{~Hz}, 3 \mathrm{H}), 0.32(\mathrm{~d}, J=6.6 \mathrm{~Hz}, 3 \mathrm{H})$. The ${ }^{1} \mathrm{H}$ NMR data matched that reported by Driver, Heyduk, Labinger, and Bercaw. 4

Table s1. Effect of counterion on yield of $\eta^{3}$-benzyl complex complex formation

\begin{tabular}{|c|c|c|c|}
\hline Entry & $\mathrm{Ar}$ & Counterion $\left(\mathrm{X}^{-}\right)$ & $\%$ Yield $^{\mathrm{a}}$ \\
\hline 1 & $3,5-t-\mathrm{Bu}_{2} \mathrm{C}_{6} \mathrm{H}_{3} \mathbf{2 a}$ & $\left(\mathrm{F}_{5} \mathrm{C}_{6}\right)_{3} \mathrm{BOCD}_{2} \mathrm{CF}_{3}$ & $>95$ \\
\hline 2 & $3,5-t-\mathrm{Bu}_{2} \mathrm{C}_{6} \mathrm{H}_{3} \mathbf{2 a}$ & OTf & 74 \\
\hline 3 & $3,5-t-\mathrm{Bu}_{2} \mathrm{C}_{6} \mathrm{H}_{3} \mathbf{2 a}$ & $\mathrm{N}(\mathrm{Tf})_{2}$ & $>95$ \\
\hline 4 & $3,5-t-\mathrm{Bu}_{2} \mathrm{C}_{6} \mathrm{H}_{3} \mathbf{2 a}$ & $\mathrm{F}_{3} \mathrm{BOCD}_{2} \mathrm{CF}_{3}$ & 72 \\
\hline 5 & $3,5-t-\mathrm{Bu}_{2} \mathrm{C}_{6} \mathrm{H}_{3} \mathbf{2 a}$ & OAc & 0 \\
\hline 6 & $3,5-t-\mathrm{Bu}_{2} \mathrm{C}_{6} \mathrm{H}_{3} \mathbf{2 a}$ & $\mathrm{O}_{2} \mathrm{CCF}_{3}$ & 0 \\
\hline 7 & $2,4,6-\mathrm{Me}_{3} \mathrm{C}_{6} \mathrm{H}_{2} \mathbf{2 b}$ & $\left(\mathrm{F}_{5} \mathrm{C}_{6}\right)_{3} \mathrm{BOCD}_{2} \mathrm{CF}_{3}$ & $>95$ \\
\hline 8 & $2,4,6-\mathrm{Me}_{3} \mathrm{C}_{6} \mathrm{H}_{2} \mathbf{2 b}$ & OTf & 90 \\
\hline 9 & $2,4,6-\mathrm{Me}_{3} \mathrm{C}_{6} \mathrm{H}_{2} \mathbf{2 b}$ & $\mathrm{N}(\mathrm{Tf})_{2}$ & 77 \\
\hline 10 & $2,4,6-\mathrm{Me}_{3} \mathrm{C}_{6} \mathrm{H}_{2} \mathbf{2 b}$ & $\mathrm{F}_{3} \mathrm{BOCD}_{2} \mathrm{CF}_{3}$ & 65 \\
\hline 11 & $2,4,6-\mathrm{Me}_{3} \mathrm{C}_{6} \mathrm{H}_{2} \mathbf{2 b}$ & $\mathrm{OAc}$ & 0 \\
\hline 12 & $2,4,6-\mathrm{Me}_{3} \mathrm{C}_{6} \mathrm{H}_{2} \mathbf{2 b}$ & $\mathrm{O}_{2} \mathrm{CCF}_{3}$ & 0 \\
\hline
\end{tabular}

${ }^{\mathrm{a}}$ Yields were determined from comparison to the peak area of $\mathrm{CF}_{3} \mathrm{CHDOD}$.

II. Diprotonolysis of platinum dimethyl 1 with triflic acid or $\mathrm{BF}_{3}$

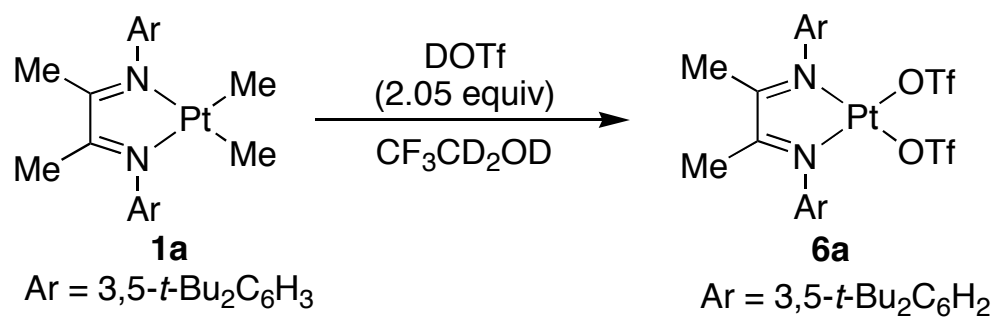

Formation of platinum triflate $3 \mathbf{a}$ from platinum dimethyl 1a. To a suspension of platinum dimethyl 1a $(0.010 \mathrm{~g}, 0.015 \mathrm{mmol})$ in $0.550 \mathrm{~mL}$ of trifluoroethanol- $d_{3}$ was added $0.150 \mathrm{~mL}$ of a $0.200 \mathrm{M}$ solution of triflic acid- $d_{1}$ (DOTf) in trifluoroethanol- $d_{3}$. The purple suspension was vigorously agitated until a light orange homogeneous solution was obtained. A portion $(0.700 \mathrm{~mL})$ of the solution was transferred to a J. Young tube and the reaction progress was analyzed periodically using ${ }^{1} \mathrm{H}$ NMR spectroscopy. After 20 minutes, ${ }^{1} \mathrm{H}$ NMR spectroscopy analysis revealed complete consumption of $\mathbf{1 a}$ and formation of $\mathbf{6 a}$ (in situ characterization data): ${ }^{1} \mathrm{H}$ NMR (300 MHz, $\mathrm{CF}_{3} \mathrm{CD}_{2} \mathrm{OD}$ ) $\delta$ 7.68-7.89 (br s, 2H), 7.07-7.26 (br s, 4H), 2.07-2.34 (br s, 6H), 1.37 (s, $36 \mathrm{H}) ;{ }^{13} \mathrm{C} \mathrm{NMR}\left(150.8 \mathrm{MHz}, \mathrm{CF}_{3} \mathrm{CD}_{2} \mathrm{OD}\right) \delta 187.8,157.3,155.9,144.1,117.7,36.7,31.6,20.4 ;{ }^{19} \mathrm{~F}$ NMR $(282$ $\left.\mathrm{MHz}, \mathrm{CF}_{3} \mathrm{CD}_{2} \mathrm{OD}\right) \delta-75.0$ (br s), -77.0 (br s).
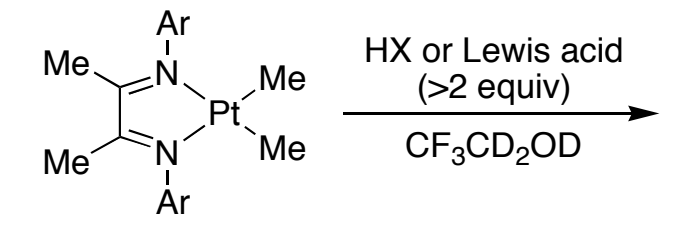

1b $\mathrm{Ar}=2,4,6-\mathrm{Me}_{3} \mathrm{C}_{6} \mathrm{H}_{2}$<smiles>CC1=C(C)N([Al])[P+]([O])([O])N1[Al]</smiles>

3b

Formation of platinum triflate $\mathbf{3 b}$ from platinum dimethyl $\mathbf{1 b}$. To a suspension of platinum dimethyl $\mathbf{1 b}$ $(0.0210 \mathrm{~g}, 0.122 \mathrm{mmol})$ in $1.00 \mathrm{~mL}$ of trifluoroethanol- $d_{3}$ was added $0.400 \mathrm{~mL}$ of a $0.200 \mathrm{M}$ solution of DOTf in trifluoroethanol- $d_{3}$. The red suspension was vigorously agitated until a light orange homogeneous solution 
was obtained. A portion $(0.700 \mathrm{~mL})$ of the solution was transferred to a J. Young tube and the reaction progress was analyzed periodically using ${ }^{1} \mathrm{H}$ NMR spectroscopy. After seven hours, ${ }^{1} \mathrm{H}$ NMR spectroscopy analysis revealed complete consumption of $\mathbf{1 b}$ and formation of $\mathbf{3 b}$ (in situ characterization data): ${ }^{1} \mathrm{H} \mathrm{NMR}(600 \mathrm{MHz}$, $\left.\mathrm{CF}_{3} \mathrm{CD}_{2} \mathrm{OD}\right) \delta 7.17(\mathrm{~s}, 2 \mathrm{H}), 7.07(\mathrm{~s}, 2 \mathrm{H}), 2.34(\mathrm{~s}, 6 \mathrm{H}), 2.33(\mathrm{~s}, 3 \mathrm{H}), 2.29(\mathrm{~s}, 9 \mathrm{H}), 2.17(\mathrm{~s}, 3 \mathrm{H}), 2.14(\mathrm{~s}, 3 \mathrm{H}) ;{ }^{13} \mathrm{C}$ NMR $\left(150.8 \mathrm{MHz}, \mathrm{CF}_{3} \mathrm{CD}_{2} \mathrm{OD}\right) \delta 188.1,187.6,144.3,143.8,140.0,139.6,132.4,131.9,131.7,131.6,21.32$, 21.30, 19.77, 19.72, 18.25, 18.15; ${ }^{19} \mathrm{~F}$ NMR (282 $\left.\mathrm{MHz}, \mathrm{CF}_{3} \mathrm{CD}_{2} \mathrm{OD}\right) \delta$-75.2, -78.6.

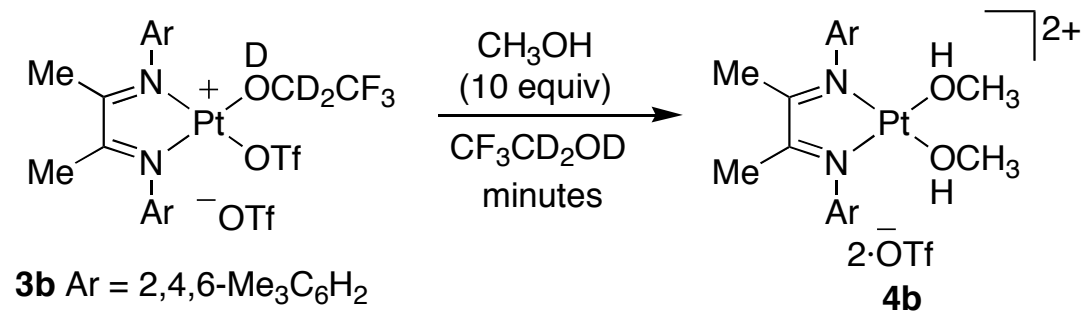

Methanolysis of platinum triflate $\mathbf{4 b}$. To a light orange solution of platinum triflate $\mathbf{4 b}(0.122 \mathrm{mmol})$ was added $0.0250 \mathrm{~mL}$ of methanol $(0.617 \mathrm{mmol})$. After five minutes, ${ }^{1} \mathrm{H}$ NMR spectroscopy analysis revealed complete consumption of unsymmetrical $\mathbf{3 b}$ and formation of symmetrical $\mathbf{4 b}$ (in situ characterization data): ${ }^{1} \mathrm{H}$ NMR (600 MHz, $\left.\mathrm{CF}_{3} \mathrm{CD}_{2} \mathrm{OD}\right) \delta 7.18(\mathrm{~s}, 4 \mathrm{H}), 2.35(\mathrm{~s}, 18 \mathrm{H}), 2.22(\mathrm{~s}, 6 \mathrm{H}) ;{ }^{13} \mathrm{C} \mathrm{NMR}\left(150.8 \mathrm{MHz}, \mathrm{CF}_{3} \mathrm{CD}_{2} \mathrm{OD}\right) \delta$ 188.3, 144.4, 139.9, 132.4, 131.6, 58.5, 21.4, 19.8, 18.2; ${ }^{19} \mathrm{~F}$ NMR (282 $\left.\mathrm{MHz}, \mathrm{CF}_{3} \mathrm{CD}_{2} \mathrm{OD}\right) \delta$-78.6.<smiles>CC1=C(C)N([Te]OC(F)(F)F)[P+]([O])([O-])N1[Al]</smiles>

3b

$\mathrm{Ar}=2,4,6-\mathrm{Me}_{3} \mathrm{C}_{6} \mathrm{H}_{2}$

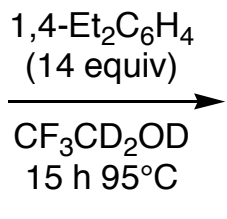

$35 \%$

Formation of $\boldsymbol{\eta}^{\mathbf{3}}$-benzyl complex $10 \mathrm{~b}$ from platinum triflate $3 \mathbf{b}$. To $0.700 \mathrm{~mL}$ of a $0.0275 \mathrm{M}$ solution of platinum triflate $\mathbf{3 b}$ in a J. Young tube was added $0.040 \mathrm{~mL}$ of 1,4 -diethylbenzene $(0.257 \mathrm{mmol})$. [The solution of $3 \mathbf{b}$ was prepared by suspending $0.021 \mathrm{~g}$ of platinum dimethyl complex $\mathbf{1 b}(0.038 \mathrm{mmol})$ in $1.400 \mathrm{~mL}$ of trifluoroethanol- $d_{3}$ and adding $0.400 \mathrm{~mL}$ of a $0.200 \mathrm{M}$ solution of DOTf in trifluoroethanol- $\left.d_{3}\right]$ The resulting mixture was heated to $95{ }^{\circ} \mathrm{C}$. The progress of the reaction was monitored periodically using ${ }^{1} \mathrm{H}$ NMR spectroscopy. After $15 \mathrm{~h}$, the reaction mixture was cooled and ${ }^{1} \mathrm{H}$ NMR spectroscopy analysis revealed partial consumption of $\mathbf{3 b}$ and formation of $\eta^{3}$-product $\mathbf{1 0 b}$ in $35 \%$ yield. Prolonged heating or the addition of basic additives did not improve the conversion.<smiles>CC1=C(C)N([Al])[P-]([O-])([O-])N1[Al]</smiles>

$6 a$

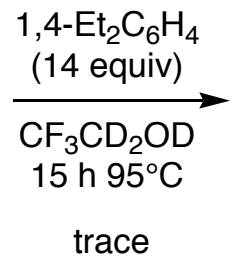

$\mathrm{Ar}=3,5-t-\mathrm{Bu}_{2} \mathrm{C}_{6} \mathrm{H}_{2}$

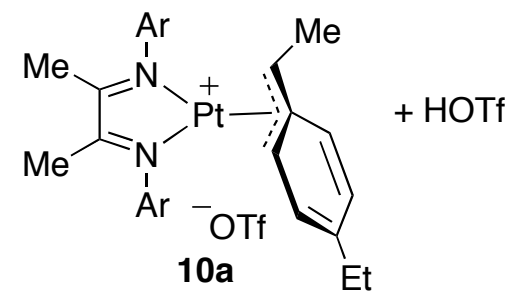

Reactivity of platinum triflate 6a towards 1,4-diethylbenzene. To a light yellow solution of platinum triflate 3a in a J. Young tube was added $0.015 \mathrm{~mL}$ of 1,4 -diethylbenzene $(0.096 \mathrm{mmol})$. [The solution of 3a was prepared by suspending $0.010 \mathrm{~g}$ of platinum dimethyl complex 1a $(0.015 \mathrm{mmol})$ in $0.550 \mathrm{~mL}$ of 
trifluoroethanol- $d_{3}$ and adding $0.400 \mathrm{~mL}$ of a $0.200 \mathrm{M}$ solution of DOTf in trifluoroethanol- $d_{3}$ ] The resulting mixture was heated to $95{ }^{\circ} \mathrm{C}$. After $15 \mathrm{~h}$, the reaction mixture was cooled and ${ }^{1} \mathrm{H}$ NMR spectroscopy analysis revealed partial formation of $\mathbf{1 0 a}(7 \%)$. Prolonged heating did not improve the conversion.

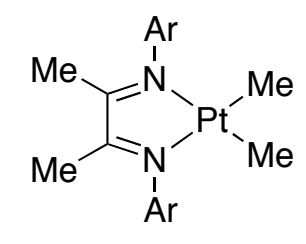

$\operatorname{Ar}=3,5-t-\mathrm{Bu}_{2} \mathrm{C}_{6} \mathrm{H}_{3}$

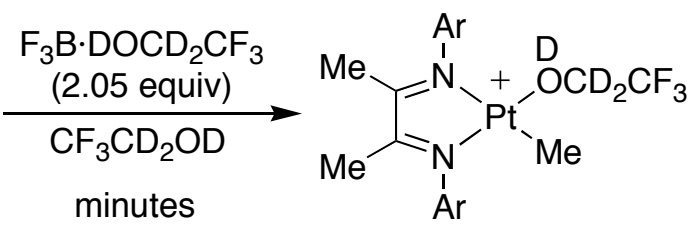

$\left[\mathrm{F}_{3} \overline{\mathrm{BOCD}} \mathrm{CF}_{3}\right]$

2a

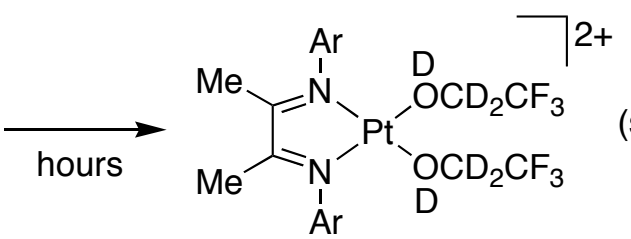

$2 \cdot\left[\mathrm{F}_{3} \overline{\mathrm{BOCD}}{ }_{2} \mathrm{CF}_{3}\right]$

$5 a$

Double protonation of platinum dimethyl 1a with $\mathbf{F}_{3} \mathbf{B} \cdot \mathbf{D O C D} \mathbf{C F}_{\mathbf{3}}$. To a suspension of platinum dimethyl $1 \mathbf{a}(0.010 \mathrm{~g}, 0.015 \mathrm{mmol})$ in $0.700 \mathrm{~mL}$ of trifluoroethanol- $d_{3}$ was added $0.070 \mathrm{~mL}$ of a $0.455 \mathrm{M}$ solution of $\mathrm{BF}_{3}$ in trifluoroethanol- $d_{3}$. The reaction progress was analyzed periodically using ${ }^{1} \mathrm{H}$ NMR spectroscopy. After 15 $\mathrm{h}$, analysis revealed complete consumption of $\mathbf{1 a}$ and formation of $\mathbf{5 a}$ (in situ characterization): ${ }^{1} \mathrm{H}$ NMR (300 $\mathrm{MHz}, \mathrm{CF}_{3} \mathrm{CD}_{2} \mathrm{OD}$ ) $\delta 7.84$ (br s, $2 \mathrm{H}$ ), 7.35 (br s, 4H), 2.32 (br s, 6H), 1.38 (br s, 36H); ${ }^{13} \mathrm{C} \mathrm{NMR}(125 \mathrm{MHz}$, $\left.\mathrm{CF}_{3} \mathrm{CD}_{2} \mathrm{OD}\right) \delta 189.8,157.9,144.6,127.8,117.9,37.0,31.8,20.6 ;{ }^{19} \mathrm{~F} \mathrm{NMR}\left(282 \mathrm{MHz}, \mathrm{CF}_{3} \mathrm{CD}_{2} \mathrm{OD}\right) \delta-77.3,-$ 150.5 (br s).

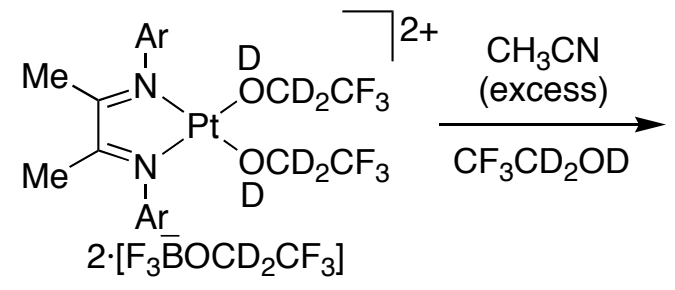

5 a

$\mathrm{Ar}=3,5-\mathrm{t}-\mathrm{Bu}_{2} \mathrm{C}_{6} \mathrm{H}_{3}$

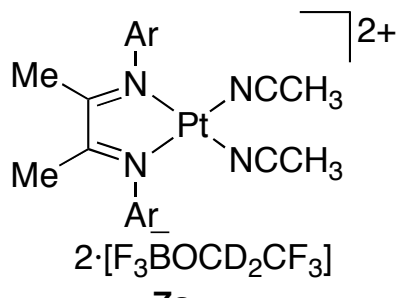

$7 \mathrm{a}$

Addition of acetonitrile to platinum dication 5a. To a light orange solution of platinum dication 5a $(0.0225$ $\mathrm{mmol})$ was added $0.050 \mathrm{~mL}$ of acetonitrile $(0.957 \mathrm{mmol})$. The resulting orange solution was concentrated in vacuo to $0.023 \mathrm{~g}$ of a yellow crystalline solid $(93 \%):{ }^{1} \mathrm{H} \mathrm{NMR}\left(300 \mathrm{MHz}, \mathrm{CD}_{2} \mathrm{Cl}_{2}\right) \delta 7.52(\mathrm{t}, J=1.8 \mathrm{~Hz}, 2 \mathrm{H})$, $7.25(\mathrm{~d}, J=1.5 \mathrm{~Hz}, 4 \mathrm{H}), 2.33(\mathrm{~s}, 6 \mathrm{H}), 2.10(\mathrm{~s}, 6 \mathrm{H}), 1.35(\mathrm{~s}, 36 \mathrm{H}),{ }^{13} \mathrm{C}$ NMR $\left(150.8 \mathrm{MHz}, \mathrm{CF}_{3} \mathrm{CD}_{2} \mathrm{OD}\right) \delta 188.9$, $156.9,145.4,124.7,122.5,117.4,37.0,32.0,21.0,2.5 ;{ }^{19} \mathrm{~F} \mathrm{NMR}\left(282 \mathrm{MHz}, \mathrm{CF}_{3} \mathrm{CD}_{2} \mathrm{OD}\right) \delta-77.3,-151.3$ (br s).

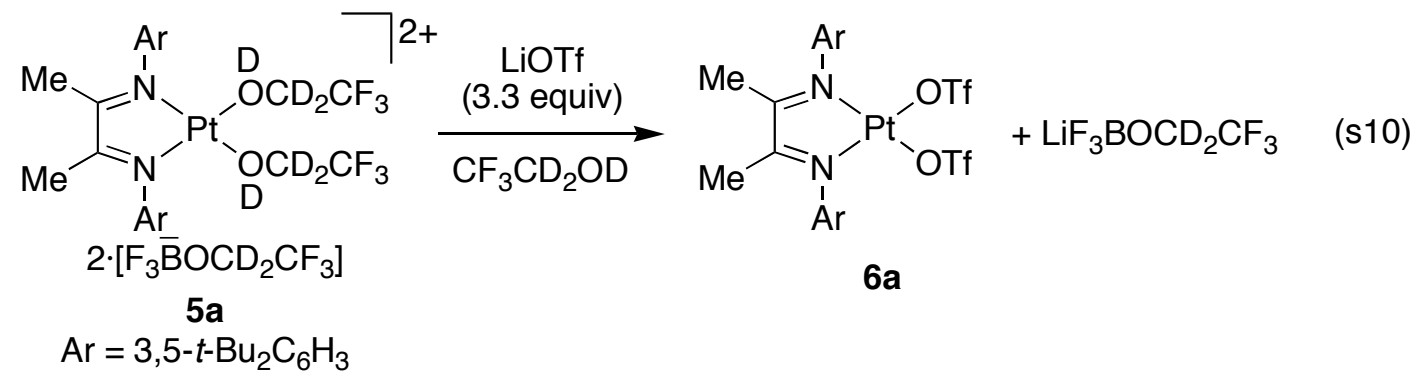

Addition of triflate to platinum dication 5a. To $0.700 \mathrm{~mL}$ of a $0.014 \mathrm{M}$ solution of platinum dication 5a was added $0.0050 \mathrm{~g}$ of LiOTf $(0.032 \mathrm{mmol}) .{ }^{1} \mathrm{H}$ NMR spectroscopy analysis revealed complete consumption of 5a and formation of symmetrical 6a. To the resulting reaction mixture was added $0.040 \mathrm{~mL}$ of 1,4-diethylbenzene $(0.257 \mathrm{mmol})$. The mixture was heated to $50{ }^{\circ} \mathrm{C}$. After $24 \mathrm{~h}$, the reaction mixture was cooled to room temperature, and ${ }^{1} \mathrm{H}$ NMR spectroscopy analysis revealed partial conversion to $\eta^{3}$-benzyl 10a $(26 \%)$. 


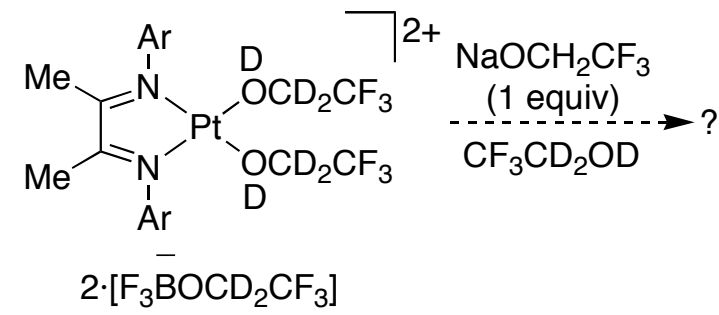

$5 \mathrm{a} \mathrm{Ar}=3,5-t-\mathrm{Bu}_{2} \mathrm{C}_{6} \mathrm{H}_{3}$<smiles></smiles>

Effect of pH on the structure of platinum dication 5a. To $0.0019 \mathrm{~g}$ of $\mathrm{NaOCH}_{2} \mathrm{CF}_{3}(0.015 \mathrm{mmol})$ was added 0.700 of a $0.020 \mathrm{M}$ solution of platinum dication $\mathbf{5 a}$ in trifluoroethanol- $d_{3}$. The light orange solution immediately turned dark red. ${ }^{1} \mathrm{H}$ NMR spectroscopy analysis revealed consumption of $\mathbf{5 a}$ and formation of s1a (in situ characterization). ${ }^{1} \mathrm{H} \mathrm{NMR}\left(300 \mathrm{MHz}, \mathrm{CF}_{3} \mathrm{CD}_{2} \mathrm{OD}\right) \delta 7.76$ (br s, 2H), 7.14 (br s, 4H), 1.82 (s, 6H), 1.37 (br s, 36H).

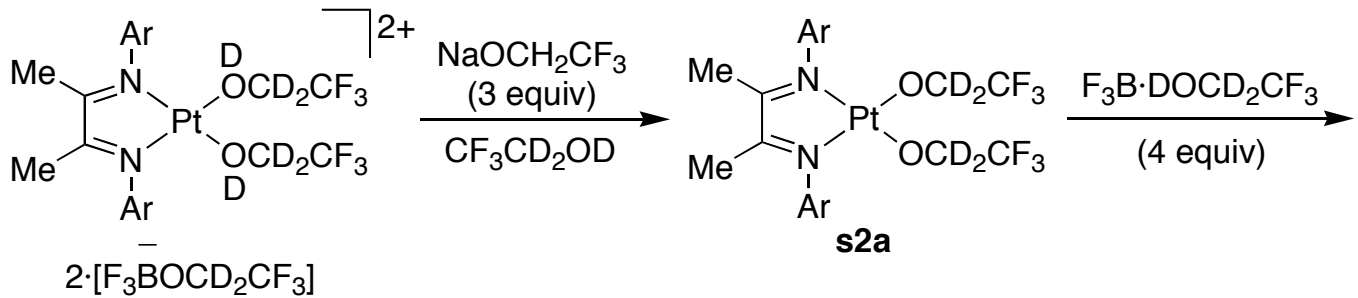

$5 \mathrm{a} \mathrm{Ar}=3,5-\mathrm{t}-\mathrm{Bu}_{2} \mathrm{C}_{6} \mathrm{H}_{3}$

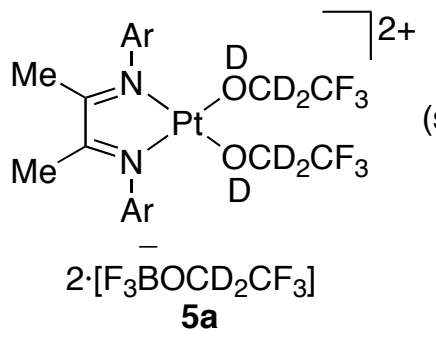

Effect of $\mathbf{p H}$ on the structure of platinum dication 5a-dual deprotonation. To $0.0051 \mathrm{~g}$ of $\mathrm{NaOCH}_{2} \mathrm{CF}_{3}$ $(0.043 \mathrm{mmol})$ was added $0.700 \mathrm{~mL}$ of a $0.015 \mathrm{M}$ solution of platinum dication $\mathbf{5 a}$ in trifluoroethanol- $d_{3}$. The light orange solution immediately turned dark red and a white precipitate formed. ${ }^{1} \mathrm{H}$ NMR spectroscopy analysis revealed complete consumption of $\mathbf{5 a}$ and formation of $\mathbf{s 2 a}$ (in situ characterization): ${ }^{1} \mathrm{H}$ NMR (500 $\left.\mathrm{MHz}, \mathrm{CF}_{3} \mathrm{CD}_{2} \mathrm{OD}\right) \delta 7.66(\mathrm{t}, J=1.5 \mathrm{~Hz}, 2 \mathrm{H}), 7.06(\mathrm{~d}, J=1.8 \mathrm{~Hz}, 4 \mathrm{H}), 1.72(\mathrm{~s}, 6 \mathrm{H}), 1.37(\mathrm{~s}, 36 \mathrm{H}) ;{ }^{13} \mathrm{C} \mathrm{NMR}$ $\left(125 \mathrm{MHz}, \mathrm{CF}_{3} \mathrm{CD}_{2} \mathrm{OD}\right) \delta 181.5,155.2,146.7,125.5,118.13,36.6,31.9,31.8$. Addition of $0.100 \mathrm{~mL}$ of a 0.478 $\mathrm{M}$ solution of $\mathrm{BF}_{3}$ in trifluoroethanol- $d_{3}$ initiated a color change from dark red to light orange. ${ }^{1} \mathrm{H}$ NMR spectroscopy analysis revealed complete consumption of $\mathbf{s} \mathbf{2} \mathbf{a}$ and formation of $\mathbf{5} \mathbf{a}$. 
III. Generality of double protonation of $\mathrm{Ar}_{2}(\mathrm{NN}) \mathrm{PtMe} \mathrm{e}_{2}$ with $\mathrm{F}_{3} \mathrm{~B} \cdot \mathrm{DOCD} \mathrm{CF}_{3}$ and reactivity of platinum dications

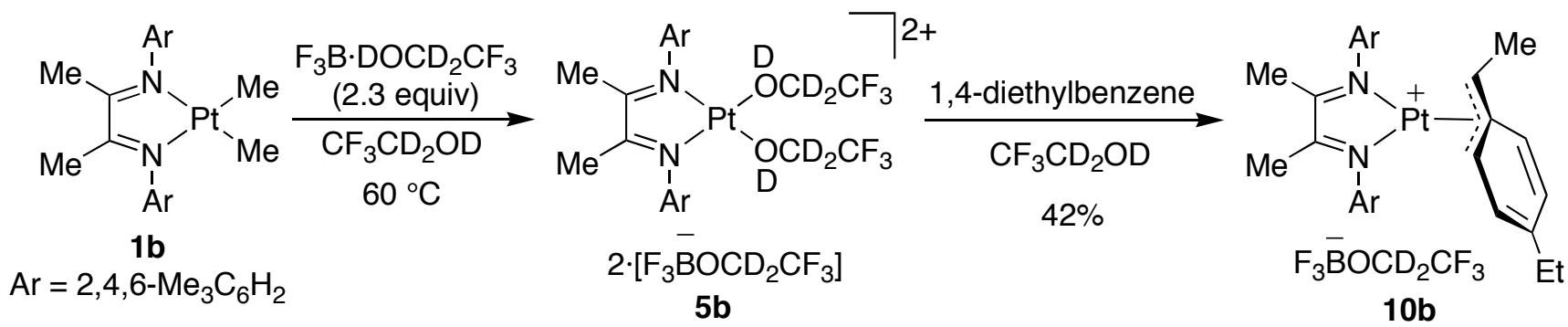

Reactivity of platinum dication 5b. To a purple suspension of platinum dimethyl $\mathbf{1 b}(0.0080 \mathrm{~g}, 0.015 \mathrm{mmol})$ was added $0.070 \mathrm{~mL}$ of a $0.455 \mathrm{M}$ solution of $\mathrm{BF}_{3}$ in trifluoroethanol- $d_{3}$. After brief agitation, the suspension became a light orange homogeneous solution. The reaction mixture was heated to $40{ }^{\circ} \mathrm{C}$. After $16 \mathrm{~h}$, the reaction mixture was cooled to room temperature, and ${ }^{1} \mathrm{H}$ NMR analysis revealed only partial consumption of platinum methyl cation $\mathbf{2 b}(50 \%)$. The reaction mixture was heated to $60{ }^{\circ} \mathrm{C}$. After $9 \mathrm{~h},{ }^{1} \mathrm{H}$ NMR analysis revealed complete consumption of $\mathbf{2} \mathbf{b}$ and the formation of several new platinum complexes (in situ characterization): ${ }^{1} \mathrm{H}$ NMR $\left(300 \mathrm{MHz}, \mathrm{CF}_{3} \mathrm{CD}_{2} \mathrm{OD}\right) \delta$ 6.95-7.20 (m, 4H), 2.37 (s, 3H), $2.34(\mathrm{~s}, 9 \mathrm{H}), 1.97(\mathrm{~s}$, $3 \mathrm{H}), 1.89(\mathrm{~s}, 3 \mathrm{H})$. To the reaction mixture was added $0.040 \mathrm{~mL}$ of 1,4 -diethylbenzene $(0.257 \mathrm{mmol})$ and the resulting mixture was analyzed ${ }^{1} \mathrm{H}$ NMR spectroscopy: no new platinum complexes were observed. The reaction mixture was heated to $50{ }^{\circ} \mathrm{C}$. After $35 \mathrm{~h},{ }^{1} \mathrm{H}$ NMR analysis revealed partial formation of $\eta^{3}$-benzyl complex (42\%). Prolonged heating did not improve the conversion.
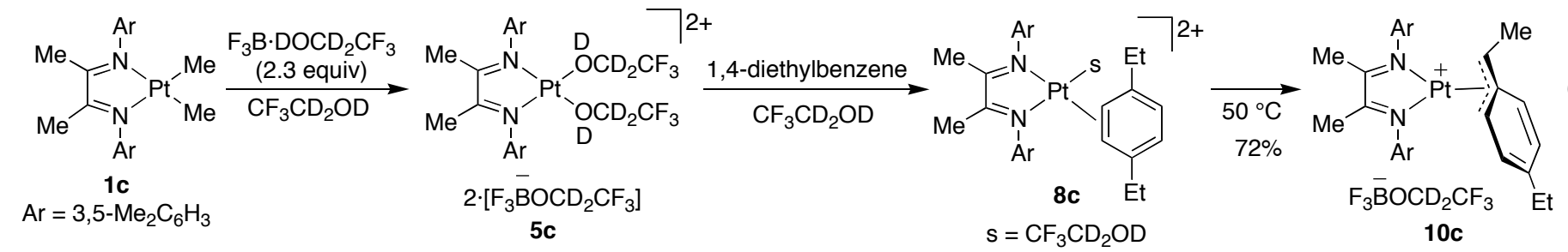

Reactivity of platinum dication 5c. To a purple suspension of platinum dimethyl $1 \mathrm{c}(0.0077 \mathrm{~g}, 0.015 \mathrm{mmol})$ was added $0.080 \mathrm{~mL}$ of a $0.455 \mathrm{M}$ solution of $\mathrm{F}_{3} \mathrm{~B}$ in trifluoroethanol- $d_{3}$. After brief agitation, the suspension became a light orange homogeneous solution. After $15 \mathrm{~h},{ }^{1} \mathrm{H}$ NMR analysis revealed complete consumption of platinum methyl cation 2c and formation of dication 5c (in situ characterization): ${ }^{1} \mathrm{H} \mathrm{NMR}(300 \mathrm{MHz}$, $\mathrm{CF}_{3} \mathrm{CD}_{2} \mathrm{OD}$ ) $\delta 7.33$ (br s, 2H), 7.08 (br s, 4H), 2.42 (br s, 12H), 2.27 (br s, 6H). To the reaction mixture was added $0.050 \mathrm{~mL}$ of 1,4-diethylbenzene $(0.321 \mathrm{mmol})$ and the resulting mixture was analyzed ${ }^{1} \mathrm{H}$ NMR spectroscopy: a mixture of the dication and a $\pi$-arene complex was visible. Selected ${ }^{1} \mathrm{H}$ NMR data for the $\pi$ arene complex: ${ }^{1} \mathrm{H}$ NMR (300 MHz, $\left.\mathrm{CF}_{3} \mathrm{CD}_{2} \mathrm{OD}\right) \delta 7.30$ (br s, 2H), 6.91 (br s, 4H), 6.67 (s, 4H), 2.22 (br s, 6H), $2.04(\mathrm{q}, J=7.5 \mathrm{~Hz}, 4 \mathrm{H}), 1.92(\mathrm{~s}, 6 \mathrm{H})$. The reaction mixture was heated to $50{ }^{\circ} \mathrm{C}$. After $13 \mathrm{~h},{ }^{1} \mathrm{H}$ NMR analysis revealed formation of $\eta^{3}$-benzyl complex in $72 \%$. Prolonged heating did not improve the conversion. ${ }^{1} \mathrm{H}$ NMR (300 MHz, $\left.\mathrm{CF}_{3} \mathrm{CD}_{2} \mathrm{OD}\right) \delta 7.06(\mathrm{~s}, 1 \mathrm{H}), 7.05(\mathrm{~s}, 1 \mathrm{H}), 6.92(\mathrm{~s}, 1 \mathrm{H}), 6.88(\mathrm{~m}, 1 \mathrm{H}), 6.68(\mathrm{~s}, 1 \mathrm{H}), 6.59(\mathrm{br} \mathrm{s}, 2 \mathrm{H})$, $6.27(\mathrm{~d}, J=7.2 \mathrm{~Hz}, 1 \mathrm{H}), 5.94(\mathrm{br} \mathrm{s}, 1 \mathrm{H}), 5.75\left(\mathrm{~d}, J=5.7 \mathrm{~Hz}, J_{\mathrm{PtH}}=48 \mathrm{~Hz}, 1 \mathrm{H}\right), 2.81\left(\mathrm{q}, J=6.6 \mathrm{~Hz}, J_{\mathrm{PtH}}=30\right.$ $\mathrm{Hz}, 1 \mathrm{H}), 2.39$ (br s, 6H), $2.10(\mathrm{~m}, 2 \mathrm{H}), 1.89$ (s, 3H), $1.82(\mathrm{~s}, 3 \mathrm{H}), 1.01$ (t, $J=7.5 \mathrm{~Hz}, 3 \mathrm{H}), 0.38(\mathrm{~d}, J=5.1 \mathrm{~Hz}$, $3 \mathrm{H})$. The ${ }^{1} \mathrm{H}$ NMR data matched that reported by Driver, Heyduk, Labinger, and Bercaw. ${ }^{4}$ 


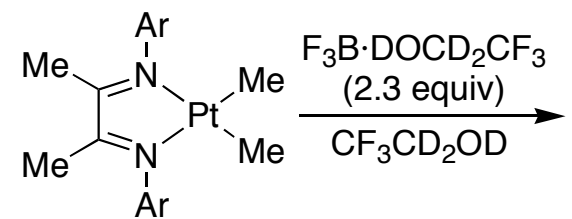

$1 d$

$\mathrm{Ar}=3,5-\left(\mathrm{F}_{3} \mathrm{C}\right)_{2} \mathrm{C}_{6} \mathrm{H}_{3}$

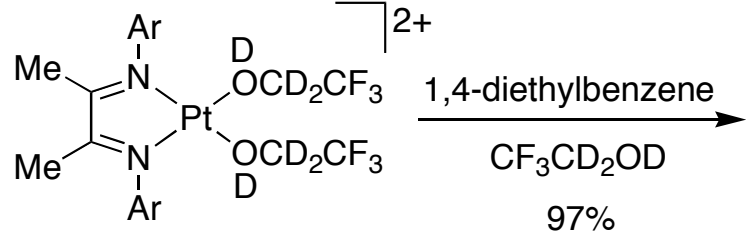

$2 \cdot\left[\mathrm{F}_{3} \mathrm{BOCD}_{2} \mathrm{CF}_{3}\right]$

$5 \mathbf{d}$

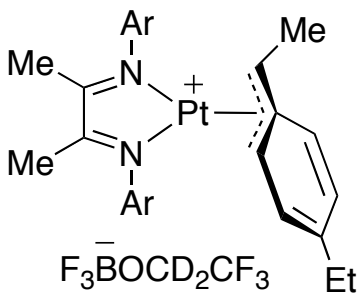

10d

Reactivity of platinum dication 5d. To a suspension of platinum dimethyl $1 \mathbf{d}(0.010 \mathrm{~g}, 0.014 \mathrm{mmol})$ in 0.630 $\mathrm{mL}$ of trifluoroethanol- $d_{3}$ was added $0.080 \mathrm{~mL}$ of a $0.455 \mathrm{M}$ solution of $\mathrm{BF}_{3}$ in trifluoroethanol- $d_{3}$. After brief agitation, the purple heterogeneous mixture became an orange homogeneous solution. The reaction progress was analyzed periodically using ${ }^{1} \mathrm{H}$ NMR spectroscopy. No consumption of the platinum methyl cation $2 \mathbf{d}$ was observed at prolonged reaction times at $22^{\circ} \mathrm{C}$. The reaction mixture was heated $50{ }^{\circ} \mathrm{C}$. After $36 \mathrm{~h}$, the reaction mixture was cooled to room temperature. ${ }^{1} \mathrm{H}$ NMR spectroscopic analysis revealed a mixture of new platinum complexes: ${ }^{1} \mathrm{H}$ NMR (300 MHz, $\left.\mathrm{CF}_{3} \mathrm{CD}_{2} \mathrm{OD}\right) \delta$ 8.08-8.25 (m), 7.94-8.04 (s), 7.90 (d, J = 1.4 Hz), $7.72(\mathrm{~d}, J=$ $1.7 \mathrm{~Hz}$ ), 2.19-2.34 (br s), 2.08 (s), 2.06 (s), 2.00 (s), 1.97 (s). To the reaction mixture was added $0.050 \mathrm{~mL}$ of 1,4-diethylbenzene $(0.321 \mathrm{mmol})$. The resulting mixture was analyzed ${ }^{1} \mathrm{H}$ NMR spectroscopy: no new platinum complexes were observed. The reaction mixture was heated to $60{ }^{\circ} \mathrm{C}$. After $28 \mathrm{~h},{ }^{1} \mathrm{H}$ NMR analysis revealed complete consumption of the mixture of platinum complexes and formation of $\eta^{3}$-benzyl complex $(97 \%)$. ${ }^{1} \mathrm{H}$ NMR (300 MHz, $\left.C_{3} \mathrm{CD}_{2} \mathrm{OD}\right) \delta 8.06(\mathrm{~s}, 1 \mathrm{H}), 8.04$ (s, 1H), 7.94 (br s, 1H), 7.79 (br s, 1H), 7.62 (br s, $\left.2 \mathrm{H}\right), 7.07$ $(\mathrm{s}, 2 \mathrm{H}), 6.40(\mathrm{~s}, 1 \mathrm{H}), 5.95\left(\mathrm{~d}, J=5.4 \mathrm{~Hz}, J_{\mathrm{Pt}-\mathrm{H}}=48 \mathrm{~Hz}, 1 \mathrm{H}\right), 2.84\left(\mathrm{q}, J=5.7 \mathrm{~Hz}, J_{\mathrm{Pt}-\mathrm{H}}=66 \mathrm{~Hz}, 1 \mathrm{H}\right), 2.08(\mathrm{~m}$, $2 \mathrm{H}), 2.05(\mathrm{~s}, 3 \mathrm{H}), 1.98(\mathrm{~s}, 3 \mathrm{H}), 0.98(\mathrm{t}, J=7.5 \mathrm{~Hz}, 3 \mathrm{H}), 0.35$ (br m, 3H). ${ }^{13} \mathrm{C}$ NMR $\left(125 \mathrm{MHz}, \mathrm{CF}_{3} \mathrm{CD}_{2} \mathrm{OD}\right) \delta$ 182.0, 180.2, 150.4, 148.6, 147.7, 143.7, 137.6, 137.5, 136.1, 136.0, 135.8, 135.7, 135.0, 134.9, 129.2, 129.0, 127.7, 126.5, 125.5, 124.1 (br m), 123.4 (2 $\mathbf{C F}_{3}$ br m), 122.3 (br m), 112.8, 72.1, 43.5, 29.7, 20.8, 20.5, 14.5; ${ }^{19} \mathrm{~F}$ NMR (282 MHz, $\left.\mathrm{CF}_{3} \mathrm{CD}_{2} \mathrm{OD}\right) \delta-63.3(3 \mathrm{~F}),-63.4(3 \mathrm{~F}),-63.6(6 \mathrm{~F}),-77.2,-81.6,-151.7$; HRMS (FAB + ) $m / z$ calcd for $\mathrm{C}_{30} \mathrm{H}_{21} \mathrm{D}_{4} \mathrm{~N}_{2} \mathrm{~F}_{12} \mathrm{Pt}^{+}\left[\mathrm{M}-\left\{\mathrm{CF}_{3} \mathrm{CD}_{2} \mathrm{OBF}_{3}\right\}\right]^{+} 840.1725$, found 840.1780.

\section{Reactivity of platinum dication 5a: observation of $\pi$-arene complexes and $C-H$ bond activation.}

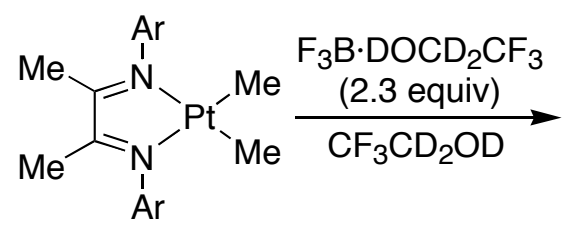

$1 \mathrm{a}$

$\mathrm{Ar}=3,5-t-\mathrm{Bu}_{2} \mathrm{C}_{6} \mathrm{H}_{3}$

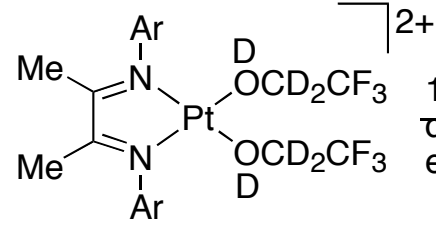

$2 \cdot\left[\mathrm{F}_{3} \overline{\mathrm{BOCD}} \mathrm{CF}_{3}\right]$

$5 a$

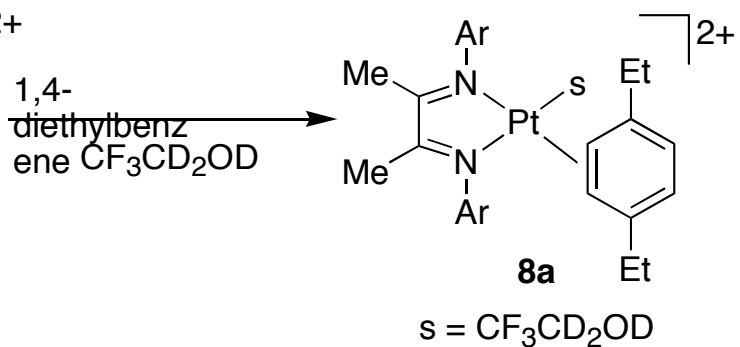

$(s 16)$

$\boldsymbol{\pi}$-Arene 8a $(\mathbf{R}=\mathbf{E t})$. To a suspension of platinum dimethyl 1a $(0.0149 \mathrm{~g}, 0.022 \mathrm{mmol})$ in $0.600 \mathrm{~mL}$ of trifluoroethanol- $d_{3}$ was added $0.110 \mathrm{~mL}$ of a $0.455 \mathrm{M}$ solution of $\mathrm{BF}_{3}$ in trifluoroethanol- $d_{3}$. After brief agitation, the purple heterogeneous mixture became a light orange homogeneous solution. After $9 \mathrm{~h}, 0.050 \mathrm{~mL}$ of 1,4-diethylbenzene $(0.321 \mathrm{mmol})$ to the resulting reaction mixture was added. Analysis of the resulting mixture using ${ }^{1} \mathrm{H}$ NMR spectroscopy revealed formation of $\pi$-arene complex 8a $(\mathrm{R}=\mathrm{Et}):{ }^{1} \mathrm{H} \mathrm{NMR}(300 \mathrm{MHz}$, $\left.\mathrm{CF}_{3} \mathrm{CD}_{2} \mathrm{OD}\right) \delta 7.73(\mathrm{t}, J=1.8 \mathrm{~Hz}, 2 \mathrm{H}), 7.22(\mathrm{~d}, J=1.5 \mathrm{~Hz}, 4 \mathrm{H}), 6.77(\mathrm{~s}, 4 \mathrm{H}), 2.41(\mathrm{~s}, 6 \mathrm{H}), 1.88(\mathrm{q}, J=7.5 \mathrm{~Hz}$, $4 \mathrm{H}), 1.43(\mathrm{~s}, 36 \mathrm{H}), 1.12(\mathrm{t}, J=7.5 \mathrm{~Hz}, 6 \mathrm{H}) .{ }^{13} \mathrm{C} \mathrm{NMR}\left(125 \mathrm{MHz}, \mathrm{CF}_{3} \mathrm{CD}_{2} \mathrm{OD}\right) \delta 181.3,157.1,150.4,143.5$, 132.4, 117.0, 113.6; 36.7, 31.9, 27.2, 20.0, 13.0; ${ }^{19} \mathrm{~F}$ NMR (282 $\left.\mathrm{MHz}, \mathrm{CF}_{3} \mathrm{CD}_{2} \mathrm{OD}\right) \delta-77.2,-150.9$. Equilibrium constants were determined by comparison of the diimine methyl signals of both the platinum dication $5 \mathbf{a}$ and $\pi$-arene complex $8 \mathbf{a}(\mathrm{R}=\mathrm{Et})$. 


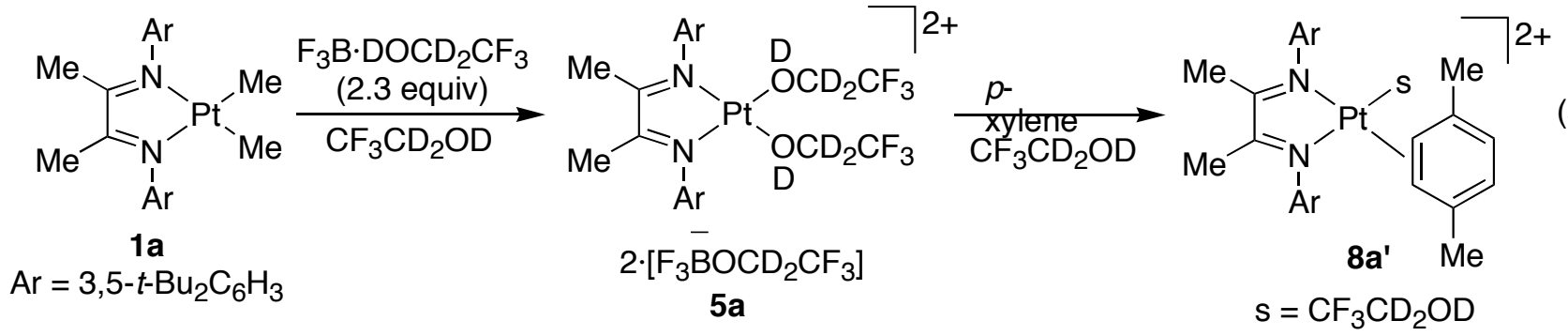

$\pi$-Arene 8a' $(\mathbf{R}=\mathbf{M e})$. To $0.700 \mathrm{~mL}$ of a $0.014 \mathrm{M}$ solution of platinum dication $\mathbf{5 a}$ in trifluoroethanol- $d_{3}$ was added $0.011 \mathrm{~mL}$ of $p$-xylene $(0.0875 \mathrm{mmol})$. [The solution of 5a was prepared by dissolving $0.060 \mathrm{~g}$ of platinum dimethyl 1a $(0.088 \mathrm{mmol})$ in $1.60 \mathrm{~mL}$ of trifluoroethanol- $d_{3}$ and adding $0.400 \mathrm{~mL}$ of a $0.478 \mathrm{M}$ solution of $\mathrm{BF}_{3}$ in trifluoroethanol- $d_{3}$ ] After brief agitation, the light yellow solution darkened to a light orange. Analysis of the resulting mixture using ${ }^{1} \mathrm{H}$ NMR spectroscopy revealed formation of $\pi$-arene complex 8a' $(\mathrm{R}=$ $\mathrm{Me}):{ }^{1} \mathrm{H}$ NMR $\left(300 \mathrm{MHz}, \mathrm{CF}_{3} \mathrm{CD}_{2} \mathrm{OD}\right) \delta 7.73(\mathrm{t}, J=1.3 \mathrm{~Hz}, 2 \mathrm{H}), 7.20(\mathrm{~d}, J=1.4 \mathrm{~Hz}, 4 \mathrm{H}), 6.87(\mathrm{~s}, 4 \mathrm{H}), 2.43$ (s, $6 \mathrm{H}), 1.51(\mathrm{~s}, 6 \mathrm{H}), 1.41(\mathrm{~s}, 36 \mathrm{H}) ;{ }^{13} \mathrm{C} \mathrm{NMR}\left(125 \mathrm{MHz}, \mathrm{CF}_{3} \mathrm{CD}_{2} \mathrm{OD}\right) \delta$ 181.1, 157.1, 150.1, 136.6, 130.0, 117.2, 115.9, 37.0, 31.9, 19.8, 19.1; ${ }^{19} \mathrm{~F}$ NMR $\left(282 \mathrm{MHz}, \mathrm{CF}_{3} \mathrm{CD}_{2} \mathrm{OD}\right) \delta-77.2,-150.7$. Equilibrium constants were determined by comparison of the diimine methyl signals of both the platinum dication $\mathbf{5 a}$ and $\pi$-arene complex 8a' $(\mathrm{R}=\mathrm{Me})$. The reaction mixture was heated to $50{ }^{\circ} \mathrm{C}$. Periodic analysis of the reaction progress using ${ }^{1} \mathrm{H}$ NMR spectroscopy revealed no formation of $\eta^{3}$-benzyl complex $\mathbf{1 0 a}$. Heating the reaction mixture to temperatures in excess of $50{ }^{\circ} \mathrm{C}$ did not result in formation of $\eta^{3}$-benzyl complex 10a. The decomposition of 8a' $(\mathrm{R}=\mathrm{Me})$ into several platinum complexes was observed.

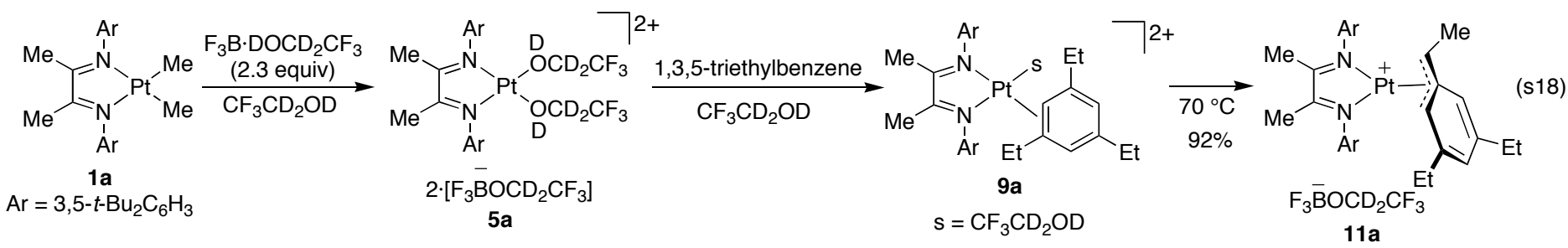

$\boldsymbol{\pi}$-Arene 9a. To $0.700 \mathrm{~mL}$ of a $0.014 \mathrm{M}$ solution of platinum dication $\mathbf{5 a}(0.0097 \mathrm{mmol})$ in trifluoroethanol- $d_{3}$ was added $0.020 \mathrm{~mL}$ of 1,3,5-triethylbenzene. [The solution of 5a was prepared by suspending $0.021 \mathrm{~g}$ of platinum dimethyl $1 \mathrm{a}(0.030 \mathrm{mmol})$ in $2.00 \mathrm{~mL}$ of trifluoroethanol- $d_{3}$.] To the resulting purple suspension was added $0.175 \mathrm{~mL}$ of a $0.478 \mathrm{M}$ solution of $\mathrm{BF}_{3}$ in trifluoroethanol- $d_{3}$. The heterogeneous mixture was agitated until a light orange homogeneous solution resulted. After $9 \mathrm{~h}$, the orange solution had faded to a light yellow solution.] Analysis of the resulting mixture using ${ }^{1} \mathrm{H}$ NMR spectroscopy revealed partial conversion to $\pi$-arene complex 9a $(25 \%)$. The reaction mixture was warmed to $50{ }^{\circ} \mathrm{C}$. After $15 \mathrm{~h}$, the orange mixture was cooled to room temperature, and analysis using ${ }^{1} \mathrm{H}$ NMR spectroscopy revealed complete formation of $\pi$-arene complex 9a: ${ }^{1} \mathrm{H}$ NMR $\left(300 \mathrm{MHz}, \mathrm{CF}_{3} \mathrm{CD}_{2} \mathrm{OD}\right) \delta 7.74(\mathrm{t}, J=1.5 \mathrm{~Hz}, 2 \mathrm{H}), 7.17(\mathrm{~d}, J=1.8 \mathrm{~Hz}, 4 \mathrm{H}), 6.91$ (s, 3H), 2.43 (s, $6 \mathrm{H}), 1.97(\mathrm{q}, J=7.5 \mathrm{~Hz}, 6 \mathrm{H}), 1.43(\mathrm{~s}, 36 \mathrm{H}), 1.71(\mathrm{t}, J=7.5 \mathrm{~Hz}, 9 \mathrm{H}) ;{ }^{13} \mathrm{C}$ NMR $\left(125 \mathrm{MHz}, \mathrm{CF}_{3} \mathrm{CD}_{2} \mathrm{OD}\right) \delta 181.8$, 157.2, 149.5, 142.3, 126.7, 121.0, 117.8, 37.2, 32.1, 28.5, 20.4, 13.4; ${ }^{19} \mathrm{~F}$ NMR $\left(282 \mathrm{MHz}, \mathrm{CF}_{3} \mathrm{CD}_{2} \mathrm{OD}\right) \delta-77.3$, -151.1. The reaction mixture was heated to $70{ }^{\circ} \mathrm{C}$. After $22 \mathrm{~h}$, the mixture was cooled to room temperature, and analysis ${ }^{1} \mathrm{H}$ NMR spectroscopy revealed partial conversion of $\pi$-arene complex $9 \mathbf{a}$ into $\eta^{3}$-benzyl complex 11a (92\%): ${ }^{1} \mathrm{H}$ NMR (300 MHz, $\left.\mathrm{CF}_{3} \mathrm{CD}_{2} \mathrm{OD}\right) \delta 7.60$ (t, $\left.J=1.8 \mathrm{~Hz}, 1 \mathrm{H}\right), 7.54(\mathrm{t}, J=1.5 \mathrm{~Hz}, 1 \mathrm{H}), 7.27$ (br s, $\left.1 \mathrm{H}\right)$, $6.93(\mathrm{~d}, J=1.8 \mathrm{~Hz}, 1 \mathrm{H}), 6.81$ (br s, 1H), 6.73 (t, $J=1.8 \mathrm{~Hz}, 1 \mathrm{H}), 6.67$ (br m, 1H, H/D exchange evident), 6.07 $(\mathrm{t}, J=1.5 \mathrm{~Hz}, 1 \mathrm{H}),(5.58$, br m, 1H, H/D exchange evident), $2.74(\mathrm{q}, J=7.8 \mathrm{~Hz}, 1 \mathrm{H}), 1.98(\mathrm{~m}, 2 \mathrm{H}), 1.94(\mathrm{~s}$, $3 \mathrm{H}), 1.76-1.88(\mathrm{~m}, 2 \mathrm{H}), 1.77(\mathrm{~s}, 3 \mathrm{H}), 1.42$ (br s, 9H), $1.39(\mathrm{~s}, 9 \mathrm{H}), 1.38$ (br s, 9H), $1.34(\mathrm{~s}, 9 \mathrm{H}), 1.16$ (t, $J=7.8$ 
$\mathrm{Hz}, 3 \mathrm{H}), 0.87(\mathrm{t}, J=7.8 \mathrm{~Hz}, 3 \mathrm{H}), 0.27(\mathrm{~d}, J=7.8 \mathrm{~Hz}, 3 \mathrm{H})$; The ${ }^{1} \mathrm{H}$ NMR data matched that reported for $11 \mathrm{a}$ by Driver, Labinger, and Bercaw. ${ }^{5}$

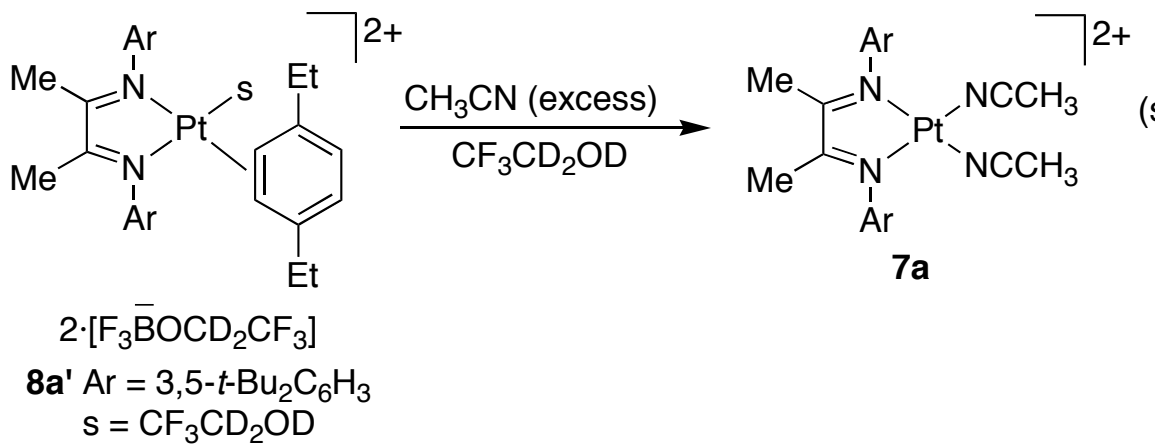

Ligand substitution of $\pi$-arene complex with acetonitrile. To a solution of $\pi$-arene complex 8a' (0.012 mmol) was added $0.050 \mathrm{~mL}$ of acetonitrile $(0.95 \mathrm{mmol})$. Analysis of the resulting mixture using ${ }^{1} \mathrm{H}$ NMR spectroscopy revealed consumption of $\pi$-arene complex 8a' and formation of diacetonitrile adduct $\mathbf{7 a}$.

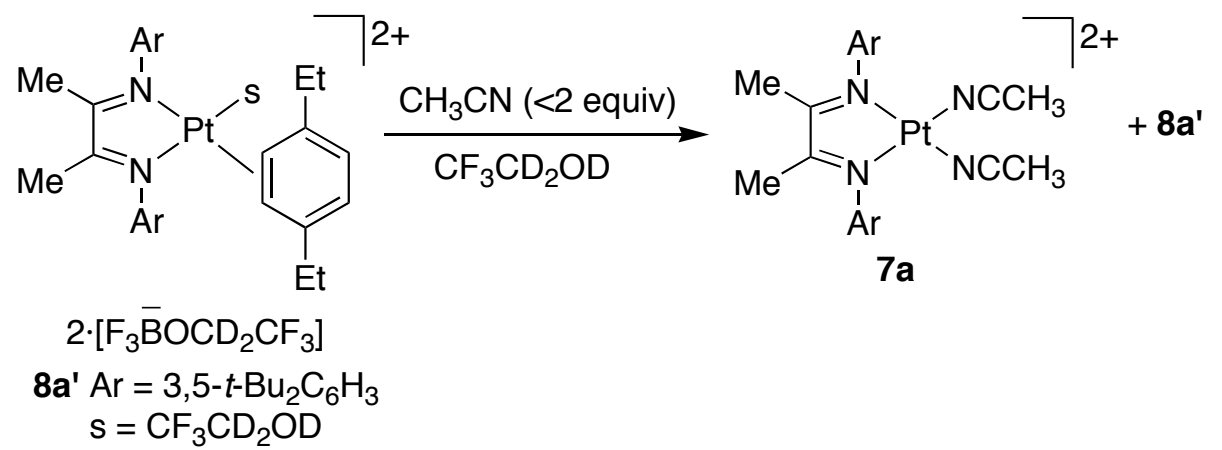

Ligand substitution of $\pi$-arene complex with acetonitrile. To a solution of $\pi$-arene complex 8a' $(0.012$ mmol) was added $0.001 \mathrm{~mL}$ of acetonitrile $(0.019 \mathrm{mmol})$. Analysis of the resulting mixture using ${ }^{1} \mathrm{H}$ NMR spectroscopy revealed partial consumption of $\pi$-arene complex 8a' and formation of diacetonitrile adduct 7a $(63 \%)$.
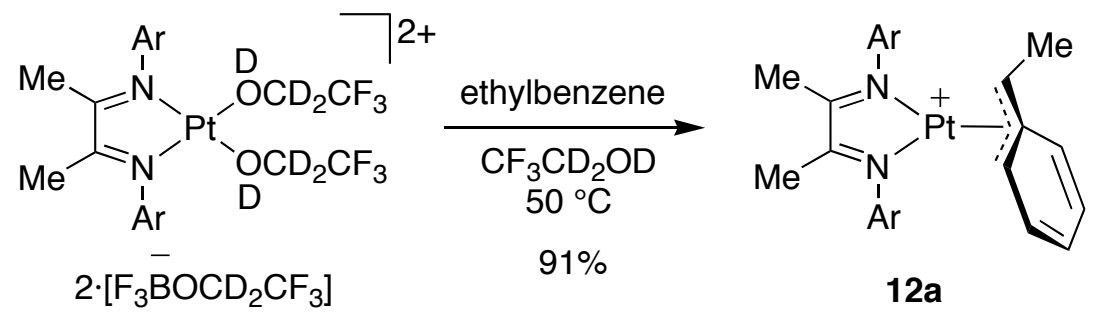

12a

$5 \mathrm{a} \mathrm{Ar}=3,5-t-\mathrm{Bu}_{2} \mathrm{C}_{6} \mathrm{H}_{3}$

$$
+\mathrm{F}_{3} \mathrm{~B}+\mathrm{HOCD}_{2} \mathrm{CF}_{3}
$$

$\eta^{3}$-Benzyl complex 12a. To $0.700 \mathrm{~mL}$ of a $0.014 \mathrm{M}$ solution of platinum dication 5a in trifluoroethanol- $d_{3}$ was added $0.025 \mathrm{~mL}$ of ethylbenzene $(0.200 \mathrm{mmol})$. [The solution of 5a was prepared by suspending $0.021 \mathrm{~g}$ of platinum dimethyl 1a $(0.030 \mathrm{mmol})$ in $2.00 \mathrm{~mL}$ of trifluoroethanol- $d_{3}$ and adding $0.175 \mathrm{~mL}$ of a $0.478 \mathrm{M}$ solution of $\mathrm{BF}_{3}$ in trifluoroethanol- $d_{3}$.] The resulting light yellow solution was heated to $50{ }^{\circ} \mathrm{C}$. After $15 \mathrm{~h}$, the reaction mixture was cooled to room temperature, and analysis using ${ }^{1} \mathrm{H}$ NMR spectroscopy revealed complete consumption of $\mathbf{5 a}$ and formation of $\eta^{3}$-benzyl complex 12a $(91 \%):{ }^{1} \mathrm{H}$ NMR $\left(300 \mathrm{MHz}, \mathrm{CF}_{3} \mathrm{CD}_{2} \mathrm{OD}\right) \delta 7.72(\mathrm{t}$, $J=1.8 \mathrm{~Hz}, 1 \mathrm{H}), 7.37(\mathrm{t}, J=1.8 \mathrm{~Hz}, 1 \mathrm{H}), 7.35(\mathrm{~s}, 1 \mathrm{H}), 7.05(\mathrm{~d}, J=7.8 \mathrm{~Hz}, 1 \mathrm{H}), 7.03(\mathrm{~s}, 1 \mathrm{H}), 6.89$ (br s, $1 \mathrm{H})$, $6.84(\mathrm{~m}, 1 \mathrm{H}), 6.78(\mathrm{br} \mathrm{s}, 1 \mathrm{H}), 6.36(\mathrm{~m}, 1 \mathrm{H}), 6.16(\mathrm{~s}, 1 \mathrm{H}), 5.75\left(\mathrm{~d}, J=6.6 \mathrm{~Hz}, J_{\mathrm{Pt}-\mathrm{H}}=45 \mathrm{~Hz}, 1 \mathrm{H}\right), 2.86(\mathrm{q}, J=6.6$ 
$\mathrm{Hz}, 1 \mathrm{H}), 2.15$ (s, 3H), 2.01 (s, 3H), 1.42 (s, 9H), 1.40 (br s, 9H), 1.36 (br s, 9H), 1.33 (s, 9H), 0.33 (d, $J=6.6$ $\mathrm{Hz}, 3 \mathrm{H})$. The ${ }^{1} \mathrm{H}$ NMR data matched that reported for 12a by Driver, Labinger, and Bercaw. ${ }^{5}$

\section{V. $\quad$ Mechanism of $\eta^{3}$-benzyl formation: kinetics and isotopic labeling}

a. Representative procedure

A stock solution of the platinum dication, 5a, was generated by diluting a mixture of $0.074 \mathrm{~g}$ of platinum dimethyl complex 1a $(0.109 \mathrm{mmol})$ and $0.550 \mathrm{~mL}$ of a $0.477 \mathrm{M}$ solution of $\mathrm{BF}_{3}$ in trifluoroethanol- $d_{3}$ to 5.00 $\mathrm{mL}$ with trifluoroethanol- $d_{3}$. Upon dissolution, $0.400 \mathrm{~mL}$ of the resulting $0.014 \mathrm{M}$ solution of the platinum dication $5 \mathbf{a}$ was placed in a $1 \mathrm{~mL}$ volumetric flask and $0.030 \mathrm{~mL}$ of 1,4-diethylbenzene $(0.193 \mathrm{mmol})$ was added. The resulting mixture was diluted to $1.00 \mathrm{~mL}$ with trifluoroethanol- $d_{3}$ and vigorously agitated. Upon homogeneity, $0.700 \mathrm{~mL}$ of the resulting light orange solution was transferred to a J. Young NMR tube, and the mixture was cooled to $-10{ }^{\circ} \mathrm{C}$ to prevent further reaction. The sample was inserted into the NMR probe, which had come to an equilibrium temperature of $66^{\circ} \mathrm{C}$. After briefly shimming on the sample, an array of spectra was acquired. After completion of the run, the intensity data for relating the concentrations of platinum $\pi$-arene $\mathbf{8 a}$ ' $(\mathrm{R}=\mathrm{Et})$ and $\eta^{3}$-benzyl 10a were obtained from the NMR spectra and were fit to the first-order exponential equations

$$
\begin{aligned}
{[1] } & =A e^{-k_{o b s} t}, \text { and } \\
{[2] } & =A\left(1-e^{-k_{o b s} t}\right) .
\end{aligned}
$$

Second-order rate constants were obtained from a plot of $k_{\text {obs }}$ vs [1,4-diethylbenzene] over the concentration range 0.193 to $0.578 \mathrm{M}$. The solubility of 1,4-diethylbenzene limited the concentration range.

b. Summary of kinetic data

Table s2. 1,4-Diethylbenzene

\begin{tabular}{cccccccc}
\hline Entry & $\mathrm{L}_{\mathrm{n}} \mathrm{PP}^{2+}$ & Substrate & $\mathrm{T}\left({ }^{2} \mathrm{C}\right)$ & {$[$ substrate] $(\mathrm{M})$} & $k_{\text {obs }}\left(\times 10^{4} \mathrm{~s}^{-1}\right)$ & $\mathrm{R}^{2}$-value & $\begin{array}{c}\text { Error in equation } \\
\text { fit }\left(\times 10^{4} \mathrm{~s}^{-1}\right)\end{array}$ \\
\hline 1 & $\mathbf{8 a},(\mathrm{R}=\mathrm{Et})$ & $1,4-\mathrm{Et}_{2} \mathrm{C}_{6} \mathrm{H}_{4}$ & 66 & 0.193 & 2.92 & 0.99769 & 0.06 \\
2 & $\mathbf{8 a},(\mathrm{R}=\mathrm{Et})$ & $1,4-\mathrm{Et}_{2} \mathrm{C}_{6} \mathrm{H}_{4}$ & 66 & 0.321 & 3.64 & 0.99807 & 0.07 \\
3 & $\mathbf{8 a},(\mathrm{R}=\mathrm{Et})$ & $1,4-\mathrm{Et}_{2} \mathrm{C}_{6} \mathrm{H}_{4}$ & 66 & 0.450 & 4.23 & 0.99549 & 0.1 \\
4 & $\mathbf{8 a},(\mathrm{R}=\mathrm{Et})$ & $1,4-\mathrm{Et}_{2} \mathrm{C}_{6} \mathrm{H}_{4}$ & 66 & 0.578 & 4.91 & 0.99809 & 0.1 \\
5 & $\mathbf{s 4 a}(\mathrm{R}=\mathrm{Et})$ & $1,4-\mathrm{Et}_{2} \mathrm{C}_{6} \mathrm{D}_{4}$ & 66 & 0.578 & 3.72 & 0.99708 & 0.09 \\
6 & $\mathbf{5 5 a}(\mathrm{R}=\mathrm{Et})$ & $1,4-\left(\mathrm{CD}_{3} \mathrm{CD}_{2}\right)_{2} \mathrm{C}_{6} \mathrm{H}_{4}$ & 66 & 0.578 & 4.28 & 0.99511 & 0.1 \\
\hline
\end{tabular}

Figure s1. Dependence of [1,4-diethylbenzene] on rate 

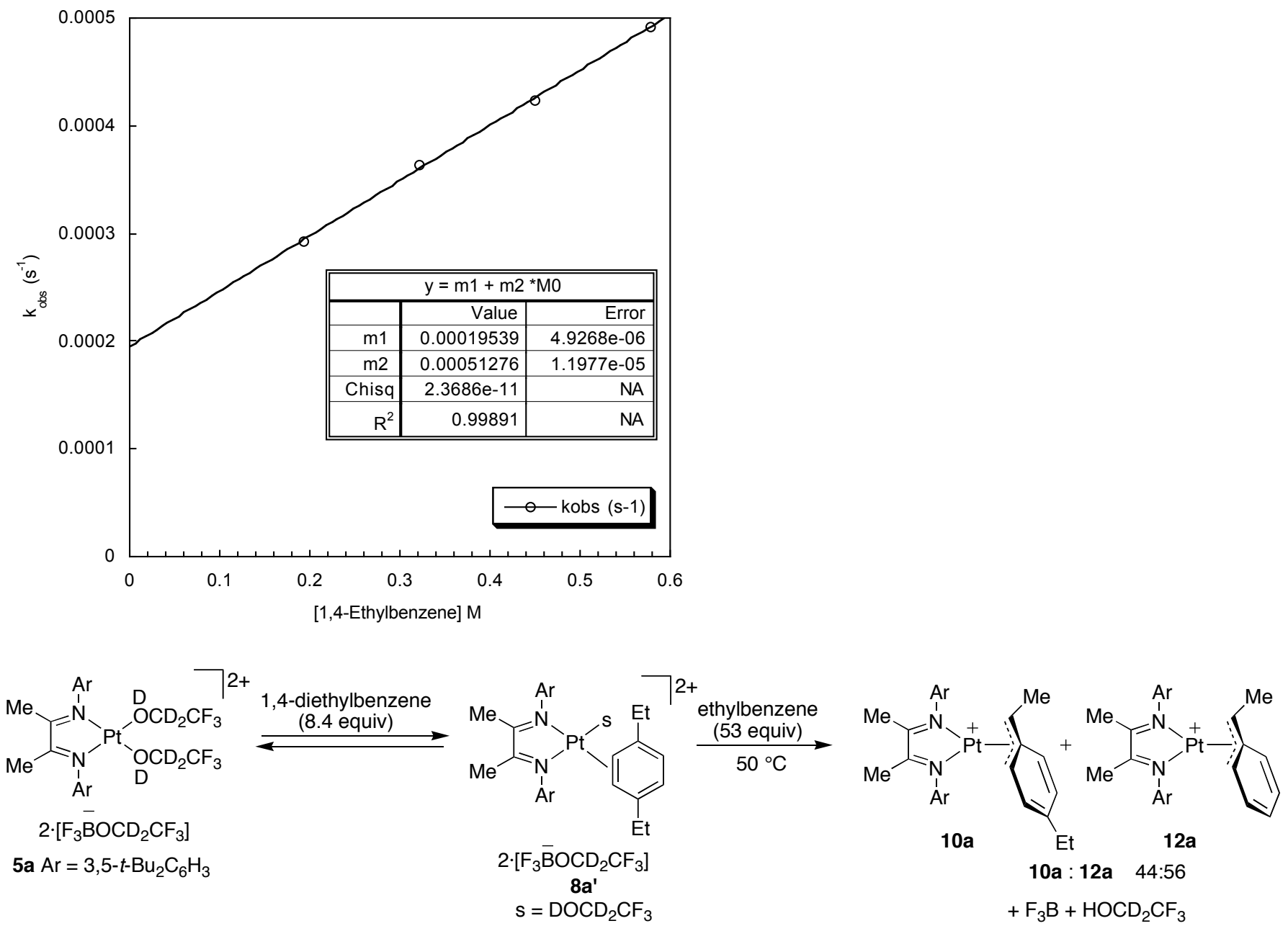

Competition reaction between platinum $\boldsymbol{\pi}$-arene $13 \mathbf{a}(\mathbf{R}=\mathbf{E t})$ and ethylbenzene. To $0.700 \mathrm{~mL}$ of a 0.022 $\mathrm{M}$ solution of platinum dication $\mathbf{5 a}$ was added $0.020 \mathrm{~mL}$ of 1,4 -diethylbenzene $(0.128 \mathrm{mmol})$. [The solution of 5a was prepared by suspending $0.030 \mathrm{~g}$ of platinum dimethyl $1 \mathrm{a}$ in $1.5 \mathrm{~mL}$ of trifluoroethanol- $d_{3}$ and adding $0.185 \mathrm{~mL}$ of a $0.455 \mathrm{M}$ solution of $\mathrm{BF}_{3}$ in trifluoroethanol- $d_{3}$. The resulting mixture was diluted to $2 \mathrm{~mL}$.] Analysis of the resulting orange solution using ${ }^{1} \mathrm{H}$ NMR spectroscopy revealed a 46:54 mixture of 5a:8a $(\mathrm{R}=$ Et). To this mixture was added $0.100 \mathrm{~mL}$ of ethylbenzene. The reaction mixture was heated to $50{ }^{\circ} \mathrm{C}$. After 20 $\mathrm{h}$, the mixture was cooled to room temperature. Analysis using ${ }^{1} \mathrm{H}$ NMR spectroscopy revealed a 44:56 mixture of 10a:12a. 

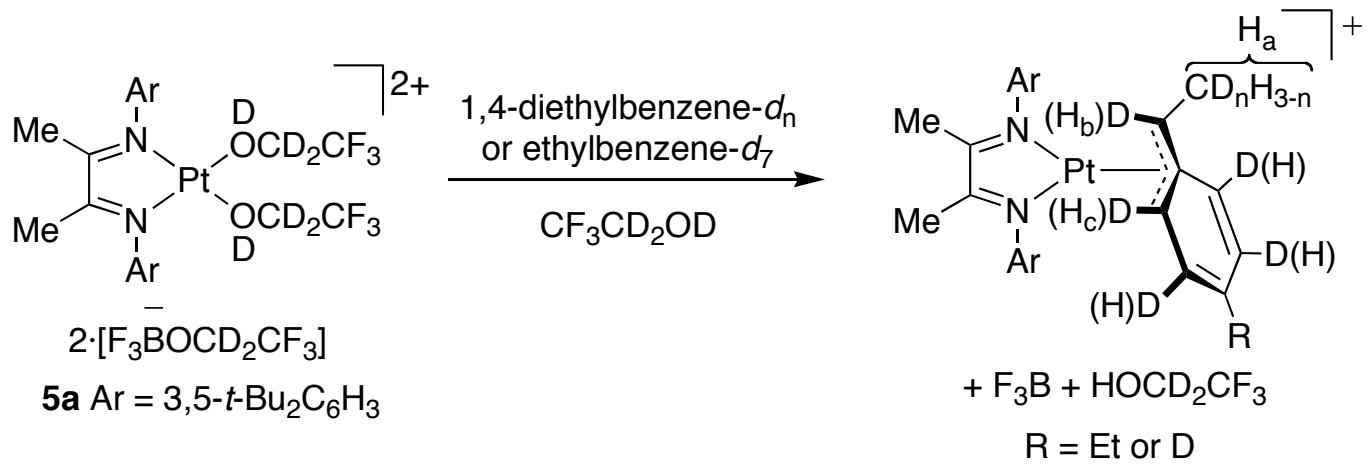

Representative procedure for ethyl- and 1,4-diethylbenzene isotopolog studies. To $0.700 \mathrm{~mL}$ of a $0.014 \mathrm{M}$ solution of platinum dication $\mathbf{5 a}$ in trifluoroethanol- $d_{3}$ was added $0.016 \mathrm{~mL}$ of 1,4-ethylbenzene- $d_{4}(0.100$ $\mathrm{mmol})$. [The solution of $\mathbf{5 a}$ was prepared by suspending $0.021 \mathrm{~g}$ of platinum dimethyl $\mathbf{1 a}(0.030 \mathrm{mmol})$ in 2.00 $\mathrm{mL}$ of trifluoroethanol- $d_{3}$ and adding $0.175 \mathrm{~mL}$ of a $0.478 \mathrm{M}$ solution of $\mathrm{BF}_{3}$ in trifluoroethanol- $d_{3}$.] The resulting light yellow solution was heated to $50{ }^{\circ} \mathrm{C}$. After $21 \mathrm{~h}$, the reaction mixture was cooled to room temperature, and analysis using ${ }^{1} \mathrm{H}$ NMR spectroscopy revealed complete consumption of 5a and formation of $\eta^{3}$-benzyl complex. The peak areas of $\mathrm{H}_{\mathrm{a}}(0.30 \mathrm{ppm}), \mathrm{H}_{\mathrm{b}}(2.82 \mathrm{ppm}), \mathrm{H}_{\mathrm{c}}(5.88 \mathrm{ppm})$ were compared for H/D isotope exchange. The resulting reaction mixture was filtered through $\mathrm{SiO}_{2}$ and the resulting clear filtrate was analyzed using GC/MS.

Table s2. Isotope exchange observed employing 5a

\begin{tabular}{|c|c|c|c|c|c|}
\hline \multirow{2}{*}{ entry } & \multirow[t]{2}{*}{ substrate } & \multicolumn{3}{|c|}{$\begin{array}{c}\% \text { Deuterium in } \\
\eta^{3} \text {-benzyl product }\end{array}$} & \multirow{2}{*}{$\begin{array}{l}\text { Molecular ion peak } \\
\text { observed in GC/MS } \\
\qquad(\mathrm{m} / \mathrm{z})\end{array}$} \\
\hline & & $\mathrm{H}_{\mathrm{a}}$ & $\mathrm{H}_{\mathrm{b}}$ & $\mathrm{H}_{\mathrm{c}}$ & \\
\hline 1 & $1,4-\left(\mathrm{CH}_{3} \mathrm{CH}_{2}\right)_{2} \mathrm{C}_{6} \mathrm{H}_{4}$ & 21 & $*$ & 65 & 138 \\
\hline 2 & $1,4-\left(\mathrm{CD}_{3} \mathrm{CD}_{2}\right)_{2} \mathrm{C}_{6} \mathrm{H}_{4}$ & 96 & 0 & 82 & 148 \\
\hline 3 & $1,4-\left(\mathrm{CH}_{3} \mathrm{CH}_{2}\right)_{2} \mathrm{C}_{6} \mathrm{D}_{4}$ & 20 & $*$ & 87 & 138 \\
\hline 4 & $\mathrm{CH}_{3} \mathrm{CH}_{2} \mathrm{C}_{6} \mathrm{H}_{5}$ & 12 & $*$ & 20 & 111 \\
\hline 5 & $\mathrm{CH}_{3} \mathrm{CD}_{2} \mathrm{C}_{6} \mathrm{D}_{5}$ & 18 & 0 & 94 & 113 \\
\hline
\end{tabular}

*could not resolve necessary peaks

VI. Other $\mathrm{C}-\mathrm{H}$ bond activations at dicationic platinum centers

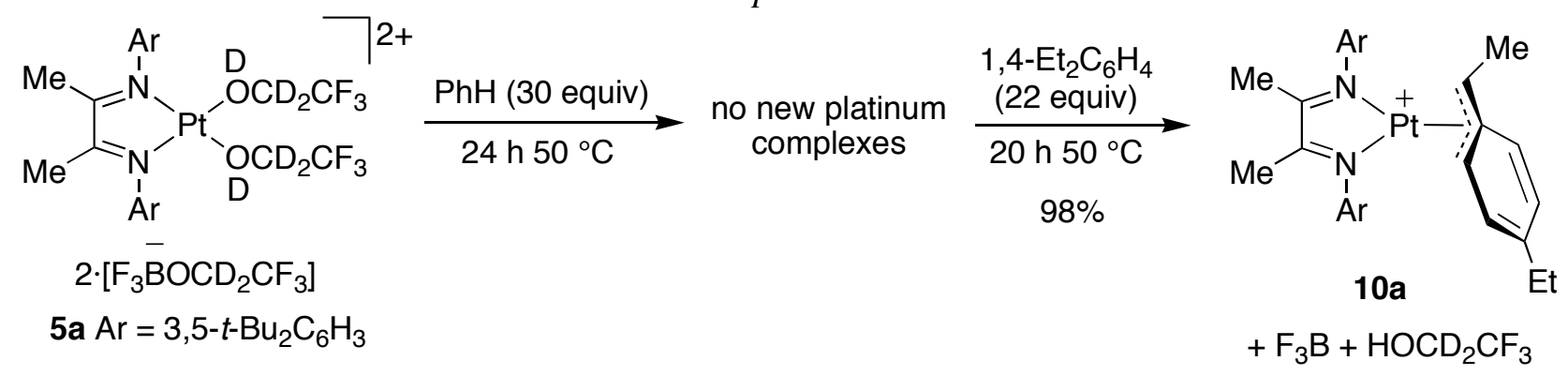

Attempted activation of benzene with platinum dication 5a. To a suspension of platinum dimethyl $1 \mathrm{a}(0.012$ $\mathrm{g}, 0.017 \mathrm{mmol}$ ) in $0.650 \mathrm{~mL}$ of trifluoroethanol- $d_{3}$ was added $0.070 \mathrm{~mL}$ of a $0.455 \mathrm{M}$ solution of $\mathrm{BF}_{3}$ in trifluoroethanol- $d_{3}$. The resulting purple suspension was agitated until a light orange homogeneous solution resulted. After $16 \mathrm{~h}, 0.040 \mathrm{~mL}$ of benzene $(0.440 \mathrm{mmol})$ was added to the now light yellow solution. The reaction progress (or lack thereof) was analyzed periodically using ${ }^{1} \mathrm{H}$ NMR spectroscopy. The reaction 
mixture was heated to $50{ }^{\circ} \mathrm{C}$. After $24 \mathrm{~h}$, the reaction mixture was cooled to room temperature. Analysis using ${ }^{1} \mathrm{H}$ NMR spectroscopy revealed no formation of the platinum phenyl cation. To the reaction mixture was added $0.050 \mathrm{~mL}$ of 1,4 -diethylbenzene $(0.321 \mathrm{mmol})$. The resulting mixture was heated to $50{ }^{\circ} \mathrm{C}$. After $20 \mathrm{~h}$, the reaction mixture was cooled to room temperature, and the reaction progress was analyzed using ${ }^{1} \mathrm{H}$ NMR spectroscopy: $\eta^{3}$-benzyl complex $\mathbf{1 0 a}$ was formed in $98 \%$ yield.

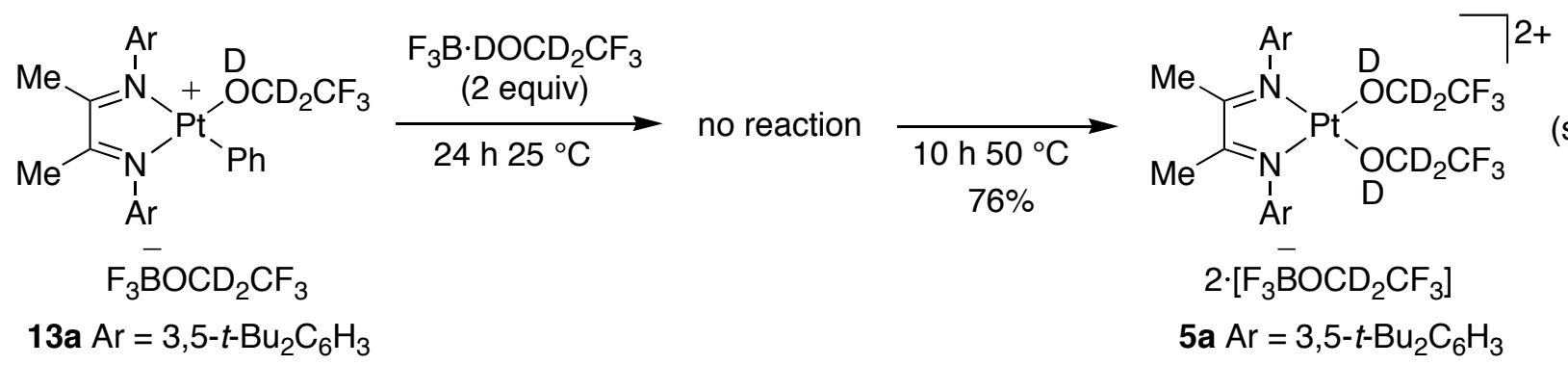

Stability of platinum phenyl cation 13a to reaction conditions. To a suspension of platinum dimethyl 1a $(0.010 \mathrm{~g}, 0.015 \mathrm{~mol})$ in $0.700 \mathrm{~mL}$ of trifluoroethanol- $d_{3}$ was added $0.032 \mathrm{~mL}$ of a $0.477 \mathrm{M}$ solution of $\mathrm{BF}_{3}$ in trifluoroethanol- $d_{3}$. The purple heterogeneous mixture was agitated. To the resulting orange solution was added $0.010 \mathrm{~mL}$ of benzene $(0.11 \mathrm{mmol})$. After $16 \mathrm{~h}$, analysis using ${ }^{1} \mathrm{H}$ NMR spectroscopy revealed consumption of platinum methyl cation 2a and formation of platinum phenyl cation 13a (in situ characterization): ${ }^{1} \mathrm{H}$ NMR $\left(300 \mathrm{MHz}, \mathrm{CF}_{3} \mathrm{CD}_{2} \mathrm{OD}\right) \delta 7.67(\mathrm{t}, J=1.8 \mathrm{~Hz}, 1 \mathrm{H}), 7.22(\mathrm{t}, J=1.5 \mathrm{~Hz}, 1 \mathrm{H}), 7.13(\mathrm{~d}$, $J=1.7 \mathrm{~Hz}, 2 \mathrm{H}), 6.84(\mathrm{~d}, J=6.6 \mathrm{~Hz}, 2 \mathrm{H}), 6.63-6.70(\mathrm{~m}, 3 \mathrm{H}), 6.60(\mathrm{~d}, J=1.8 \mathrm{~Hz}, 2 \mathrm{H}), 2.13(\mathrm{~s}, 3 \mathrm{H}), 1.92(\mathrm{~s}$, $3 \mathrm{H}), 1.39(\mathrm{~s}, 9 \mathrm{H}), 1.21(\mathrm{~s}, 9 \mathrm{H})$. The ${ }^{1} \mathrm{H}$ NMR data matched that reported for 16a by Zhong, Labinger, and Bercaw. ${ }^{3} \quad$ To the reaction mixture was added $0.040 \mathrm{~mL}$ of a $0.477 \mathrm{M}$ solution of $\mathrm{BF}_{3}$ in trifluoroethanol- $d_{3}$. After $24 \mathrm{~h}$, analysis using ${ }^{1} \mathrm{H}$ NMR spectroscopy revealed trace formation of platinum dication 5a. The reaction mixture was heated to $50{ }^{\circ} \mathrm{C}$. After $10 \mathrm{~h}$, analysis using ${ }^{1} \mathrm{H}$ NMR spectroscopy revealed complete consumption of 13a and formation of platinum dication $\mathbf{5 a}$.

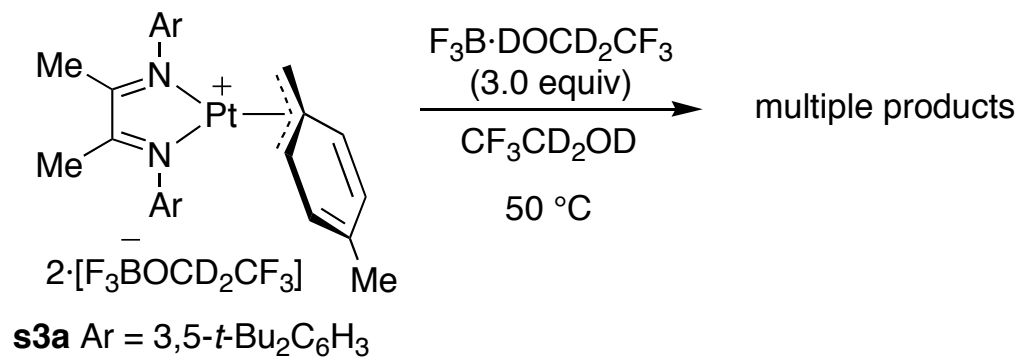

Stability of platinum $\boldsymbol{\eta}^{3}$-benzyl complex s3a to reaction conditions. To $0.700 \mathrm{~mL}$ of a $0.015 \mathrm{M}$ solution of platinum methyl cation $\mathbf{2 a}$ in trifluoroethanol- $d_{3}$ was added $0.020 \mathrm{~mL}$ of $p$-xylene $(0.163 \mathrm{mmol})$. [The solution of $2 \mathbf{a}$ was prepared by suspending of platinum dimethyl $1 \mathbf{a}(0.014 \mathrm{~g}, 0.020 \mathrm{mmol})$ in $1.4 \mathrm{~mL}$ of trifluoroethanol$d_{3}$. To the purple solution was added $0.050 \mathrm{~mL}$ of a $0.477 \mathrm{M}$ solution of $\mathrm{BF}_{3}$ in trifluoroethanol- $d_{3}$. The heterogeneous mixture was agitated until a light orange solution resulted.] The reaction mixture was heated to $50{ }^{\circ} \mathrm{C}$. After $5 \mathrm{~h}$, the mixture was cooled to room temperature. Analysis using ${ }^{1} \mathrm{H}$ NMR spectroscopy revealed complete consumption of platinum methyl cation $\mathbf{2 a}$ and formation of $\eta^{3}$-benzyl complex $\mathbf{s 4 a}$ (in situ characterization): ${ }^{1} \mathrm{H}$ NMR $\left(300 \mathrm{MHz}, \mathrm{CF}_{3} \mathrm{CD}_{2} \mathrm{OD}\right) \delta 7.61(\mathrm{t}, J=1.5 \mathrm{~Hz}, 1 \mathrm{H}), 7.58(\mathrm{t}, J=1.8 \mathrm{~Hz}, 1 \mathrm{H}), 7.06(\mathrm{br}$ s, $2 \mathrm{H}$, obscured by $p$-xylene signal), $6.69(\mathrm{~d}, J=1.5 \mathrm{~Hz}, 2 \mathrm{H}), 6.61(\mathrm{~d}, J=7.2 \mathrm{~Hz}, 2 \mathrm{H}), 6.27(\mathrm{~d}, J=7.8 \mathrm{~Hz}, 2 \mathrm{H})$, $2.62\left(\mathrm{~s}, J_{\mathrm{Pt}-\mathrm{H}}=42 \mathrm{~Hz}, 2 \mathrm{H}\right), 2.00(\mathrm{~s}, 3 \mathrm{H}), 1.89(\mathrm{~s}, 3 \mathrm{H}), 1.69(\mathrm{~s}, 3 \mathrm{H}), 1.40(\mathrm{~s}, 36 \mathrm{H})$. The ${ }^{1} \mathrm{H}$ NMR data matched that reported for 16a by Driver, Labinger, and Bercaw. ${ }^{5}$ To this solution was added $0.065 \mathrm{~mL}$ of a $0.477 \mathrm{M}$ solution of $\mathrm{BF}_{3}$ in trifluoroethanol- $d_{3}$. After $16 \mathrm{~h}$, Analysis using ${ }^{1} \mathrm{H}$ NMR spectroscopy revealed diminishment 
of s3a by $4 \%$. The reaction mixture was heated to $50{ }^{\circ} \mathrm{C}$. After $20 \mathrm{~h}$, the mixture was cooled to room temperature and analyzed using ${ }^{1} \mathrm{H}$ NMR spectroscopy: $70 \%$ of $\eta^{3}$-benzyl complex s3a had been consumed to form several new platinum complexes - none of which were platinum dication $\mathbf{5 a}$.

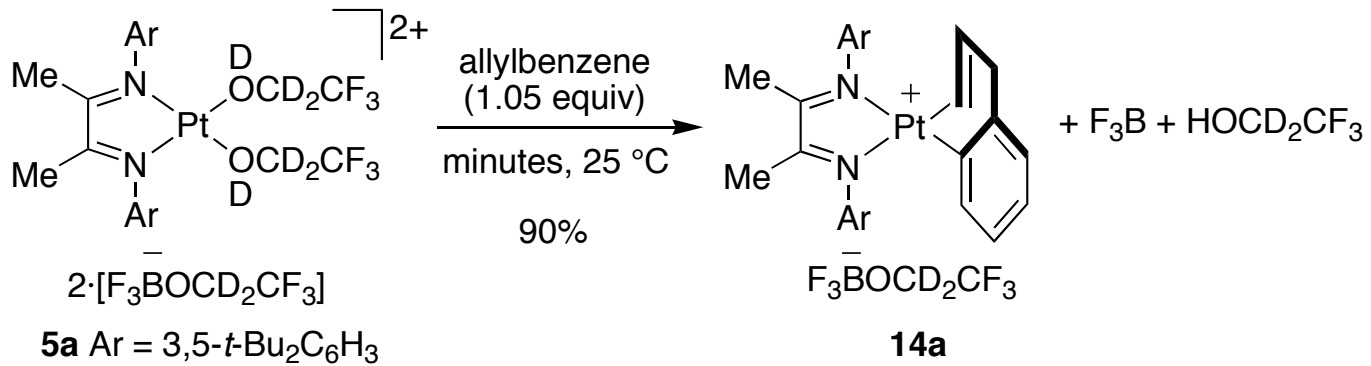

Platinum complex 14a. To a purple suspension of platinum dimethyl 1a $(0.060 \mathrm{~g}, 0.088 \mathrm{mmol})$ in $8 \mathrm{~mL}$ of trifluoroethanol was added $0.500 \mathrm{~mL}$ of a $0.477 \mathrm{M}$ solution of $\mathrm{BF}_{3}$ in trifluoroethanol- $d_{3}$. Upon brief agitation the heterogeneous mixture became an orange homogeneous solution. After $6 \mathrm{~h}, 0.0125 \mathrm{~mL}$ of allylbenzene was added to the resulting light yellow solution. Upon addition, the light yellow solution immediately darkened to a cherry apple red color. After $12 \mathrm{~h}$, the reaction mixture was concentrated in vacuo to afford $0.073 \mathrm{~g}$ of platinum complex 14a (90\%): ${ }^{1} \mathrm{H}$ NMR $\left(600 \mathrm{MHz}, \mathrm{CD}_{2} \mathrm{Cl}_{2}\right) \delta 7.42(\mathrm{t}, J=1.8 \mathrm{~Hz}, 1 \mathrm{H}), 7.32(\mathrm{t}, J=1.8 \mathrm{~Hz}, 1 \mathrm{H}), 7.14$ (br s, $1 \mathrm{H}), 6.89(\mathrm{t}, J=1.8 \mathrm{~Hz}, 1 \mathrm{H}), 6.85(\mathrm{t}, J=1.8 \mathrm{~Hz}, 1 \mathrm{H}), 6.83(\mathrm{~d}, J=7.2 \mathrm{~Hz}, 1 \mathrm{H}), 6.65(\mathrm{td}, J=7.2,1.2 \mathrm{~Hz}, 1 \mathrm{H})$, $6.53(\mathrm{br} \mathrm{s}, 1 \mathrm{H}), 6.28(\mathrm{t}, J=7.2 \mathrm{~Hz}, 1 \mathrm{H}), 5.48(\mathrm{dd}, J=7.8,1.2 \mathrm{~Hz}, 1 \mathrm{H}), 5.10\left(\mathrm{dt}, J=13.2,6.6 \mathrm{~Hz}, 1 \mathrm{H}, J_{\mathrm{Pt}-\mathrm{H}} \sim 75\right.$ $\mathrm{Hz}$ at $300 \mathrm{MHz}), 3.99(\mathrm{~d}, J=14.4 \mathrm{~Hz}, 1 \mathrm{H}), 3.91(\mathrm{dd}, J=17.4,6.3 \mathrm{~Hz}, 1 \mathrm{H}), 3.41\left(\mathrm{~d}, J=7.8 \mathrm{~Hz}, 1 \mathrm{H}, J_{\mathrm{Pt}-\mathrm{H}} \sim 63 \mathrm{at}\right.$ $300 \mathrm{MHz}), 2.72\left(\mathrm{~d}, J=16.8 \mathrm{~Hz}, 1 \mathrm{H}, J_{\mathrm{Pt}-\mathrm{H}} \sim 114 \mathrm{~Hz}\right.$ at $\left.300 \mathrm{MHz}\right), 2.53(\mathrm{~s}, 3 \mathrm{H}), 2.21(\mathrm{~s}, 3 \mathrm{H}), 1.40(\mathrm{br}$ s, $9 \mathrm{H}), 1.38$ (s, 9H), 1.34 (s, 9H), 0.94 (br s, 9H); ${ }^{13} \mathrm{C} \mathrm{NMR} \mathrm{(150.8} \mathrm{MHz,} \mathrm{CD}_{2} \mathrm{Cl}_{2}$ ) $\delta 184.1,179.2,154.1,154.0,148.5,144.2$, $144.1,137.6,133.1,126.4,124.8,124.7,124.2,122.9,122.8,122.5,119.5,117.3,115.6,114.5,108.3\left(J_{\mathrm{Pt}-\mathrm{C}}=\right.$ $205 \mathrm{~Hz}), 70.0(\mathrm{~J}=205 \mathrm{~Hz}), 39.2,35.7,31.57,31.53,31.51,31.48,31.1,21.8,21.7,21.03,21.01 ; \mathrm{IR}(\mathrm{KBr}$ pellet) 3050, 2963, 2871, 1587, 1063, 900, $557 \mathrm{~cm}^{-1}$; UV-Vis $\left(\mathrm{CF}_{3} \mathrm{CH}_{2} \mathrm{OH}\right) 200 \mathrm{~nm}\left(\varepsilon=1.62 \times 10^{5} \mathrm{M}^{-1} \cdot \mathrm{cm}^{-1}\right)$, $219 \mathrm{~nm}\left(\varepsilon=9.55 \times 10^{4} \mathrm{M}^{-1} \cdot \mathrm{cm}^{-1}\right), 276 \mathrm{~nm}\left(\varepsilon=1.93 \times 10^{4} \mathrm{M}^{-1} \cdot \mathrm{cm}^{-1}\right), 388 \mathrm{~nm}\left(\varepsilon=7.76 \times 10^{3} \mathrm{M}^{-1} \cdot \mathrm{cm}^{-1}\right)$. HRMS $(\mathrm{FAB}+) m / z$ calcd for $\mathrm{C}_{41} \mathrm{H}_{57} \mathrm{~N}_{2} \mathrm{Pt}^{+}\left[\mathrm{M}-\left\{\mathrm{CF}_{3} \mathrm{CD}_{2} \mathrm{OBF}_{3}\right\}\right]^{+}$772.4164, found 772.4162 .

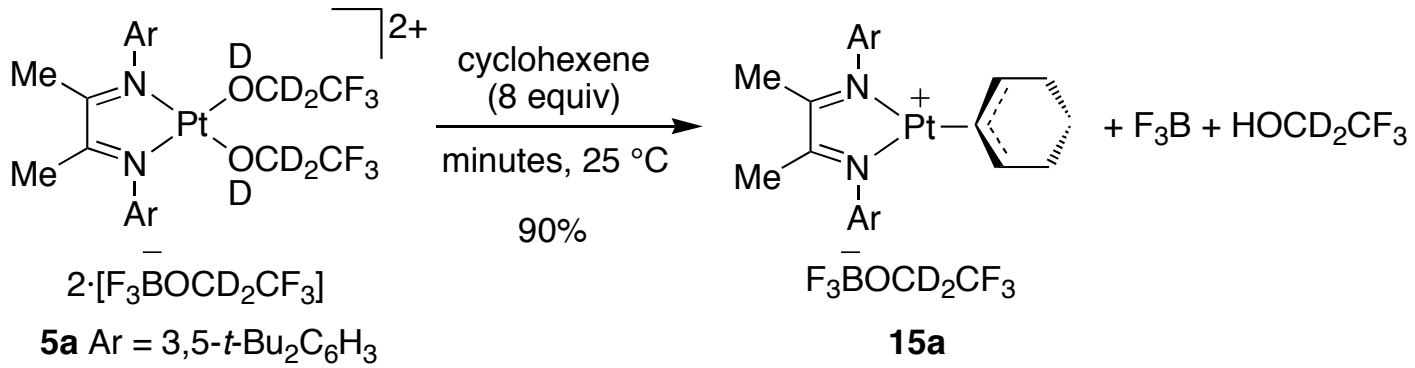

$\eta^{3}$-Allyl 15a. To a purple suspension of platinum dimethyl 1a $(0.060 \mathrm{~g}, 0.0875 \mathrm{mmol})$ in $8 \mathrm{~mL}$ of trifluoroethanol was added $0.500 \mathrm{~mL}$ of a $0.477 \mathrm{M}$ solution of $\mathrm{BF}_{3}$ in trifluoroethanol- $d_{3}$. After brief agitation, the heterogeneous mixture became an orange homogeneous solution. After $6 \mathrm{~h}, 0.018 \mathrm{~mL}$ of cyclohexene $(0.175 \mathrm{mmol})$ was added to the resulting light yellow solution. After $12 \mathrm{~h}$, the light orange solution was concentrated in vacuo to afford $0.071 \mathrm{~g}$ of $\eta^{3}$-allyl 15a as a light yellow powder $(90 \%):{ }^{1} \mathrm{H} \mathrm{NMR}(300 \mathrm{MHz}$, $\left.\mathrm{CD}_{2} \mathrm{Cl}_{2}\right) \delta 7.41(\mathrm{t}, J=1.8 \mathrm{~Hz}, 2 \mathrm{H}), 6.99(\mathrm{br} \mathrm{s}, 4 \mathrm{H}), 5.33\left(\mathrm{t}, J=6.3 \mathrm{~Hz}, 1 \mathrm{H}, J_{\mathrm{Pt}-\mathrm{H}}=84 \mathrm{~Hz}\right), 4.12(\mathrm{t}, J=6 \mathrm{~Hz}, 2 \mathrm{H}$, $\left.J_{\mathrm{Pt}-\mathrm{H}}=33 \mathrm{~Hz}\right), 2.28(\mathrm{~s}, 6 \mathrm{H}), 1.97-2.1(\mathrm{~m}, 2 \mathrm{H}), 1.42-1.55(\mathrm{~m}, 2 \mathrm{H}), 1.34(\mathrm{~s}, 36 \mathrm{H}), 0.62-0.82(\mathrm{~m}, 2 \mathrm{H}) ;{ }^{13} \mathrm{C}$ $\operatorname{NMR}\left(75.5 \mathrm{MHz}, \mathrm{CD}_{2} \mathrm{Cl}_{2}\right) \delta 177.5,153.4,148.7,122.4,115.2,100.7,63.1\left(J_{\mathrm{Pt}-\mathrm{C}}=242 \mathrm{~Hz}\right), 35.7,31.6,30.2$, 20.4, 19.4; IR (KBr pellet) 2961, 2870, 1595, 1364, 1064, 928, $711 \mathrm{~cm}^{-1}$; UV-Vis $\left(\mathrm{CF}_{3} \mathrm{CH}_{2} \mathrm{OH}\right) 202 \mathrm{~nm}(\varepsilon=$ 
$\left.1.17 \times 10^{5} \mathrm{M}^{-1} \cdot \mathrm{cm}^{-1}\right), 219 \mathrm{~nm}\left(\varepsilon=7.30 \times 10^{4} \mathrm{M}^{-1} \cdot \mathrm{cm}^{-1}\right), 276 \mathrm{~nm}\left(\varepsilon=2.32 \times 10^{4} \mathrm{M}^{-1} \cdot \mathrm{cm}^{-1}\right)$. HRMS (FAB +$) \mathrm{m} / z$ calcd for $\mathrm{C}_{38} \mathrm{H}_{57} \mathrm{~N}_{2} \mathrm{Pt}^{+}\left[\mathrm{M}-\left\{\mathrm{CF}_{3} \mathrm{CD}_{2} \mathrm{OBF}_{3}\right\}\right]^{+}$736.4170, found 736.4195.

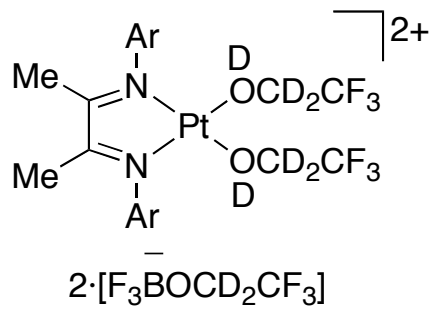

$5 \mathrm{a} \mathrm{Ar}=3,5-t-\mathrm{Bu}_{2} \mathrm{C}_{6} \mathrm{H}_{3}$

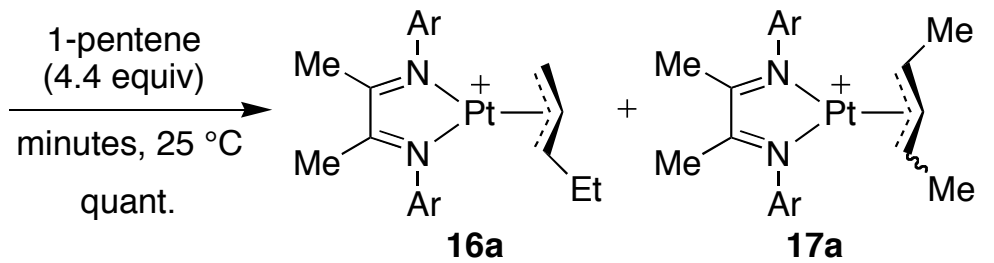

16a: 17a $26: 74$

d.r. 17a $18: 82$

$+\mathrm{F}_{3} \mathrm{~B}+\mathrm{HOCD}_{2} \mathrm{CF}_{3}$

$\eta^{3}$-Allyls 16a and 17a. To $0.700 \mathrm{~mL}$ of a $0.015 \mathrm{M}$ solution of platinum dication 5a in trifluoroethanol- $d_{3}$ was added $0.006 \mathrm{~mL}$ of 1-pentene. [The solution of $\mathbf{5 a}$ was prepared by suspending $0.022 \mathrm{~g}$ of platinum dimethyl 1a $(0.032 \mathrm{mmol})$ in $2.0 \mathrm{~mL}$ of trifluoroethanol- $d_{3}$. To the resulting purple heterogeneous mixture was added 0.175 $\mathrm{mL}$ of a $0.477 \mathrm{M}$ solution of $\mathrm{BF}_{3}$ in trifluoroethanol- $d_{3}$. After brief agitation the mixture became a light orange solution. After $6 \mathrm{~h}$, the orange solution had faded to light yellow.] After $20 \mathrm{~min}$, analysis of the reaction progress using ${ }^{1} \mathrm{H}$ NMR spectroscopy revealed complete consumption of 5a and formation of a 26:74 mixture of $\eta^{3}$-allyls 16a and 17a ( $\left.>95 \%\right)$. The diastereoselectivity of $\mathbf{1 7 a}$ was determined to be 18:82 by comparison of doublets at 0.37 and 0.24 respectively. Major diastereomer of $\eta^{3}$-allyl $\mathbf{1 7 a}:{ }^{1} \mathrm{H}$ NMR $\left(500 \mathrm{MHz}, \mathrm{CD}_{2} \mathrm{Cl}_{2}\right) \delta 7.38$ (t, $J=1.5 \mathrm{~Hz}, 2 \mathrm{H}), 7.01$ (br s, 2H), $6.76(\mathrm{br} \mathrm{s}, 2 \mathrm{H}), 4.35\left(\mathrm{t}, J=11.5 \mathrm{~Hz}, 1 \mathrm{H}, J_{\mathrm{Pt}-\mathrm{H}}=74 \mathrm{~Hz}\right.$ ), 3.18 (sextet, $J=6.5$ $\left.\mathrm{Hz}, 2 \mathrm{H}, J_{\mathrm{Pt}-\mathrm{H}}=88 \mathrm{~Hz}\right), 2.23(\mathrm{~s}, 6 \mathrm{H}), 1.35(\mathrm{~s}, 18 \mathrm{H}), 1.31(\mathrm{~s}, 18 \mathrm{H}), 0.25(\mathrm{~d}, J=6 \mathrm{~Hz}, 6 \mathrm{H}) ;{ }^{13} \mathrm{C} \mathrm{NMR}(125.7 \mathrm{MHz}$, $\left.\mathrm{CD}_{2} \mathrm{Cl}_{2}\right) \delta 177.9,154.3,154.0,147.6,122.0,114.9,111.3,108.6,61.6\left(J_{\mathrm{Pt}-\mathrm{C}}=243 \mathrm{~Hz}\right), 35.71,35.6531 .56$, 31.54, 20.3, 15.0. Selected data for regioisomer 16a: ${ }^{1} \mathrm{H}$ NMR $\left(500 \mathrm{MHz}, \mathrm{CF}_{3} \mathrm{CD}_{2} \mathrm{OD}\right) \delta 4.65(\mathrm{dt}, J=11.5 \mathrm{~Hz}$, $\left.1 \mathrm{H}, J_{\mathrm{Pt}-\mathrm{H}} \sim 75 \mathrm{~Hz}\right), 3.71\left(\mathrm{t}, J=6.5 \mathrm{~Hz}, 1 \mathrm{H}, J_{\mathrm{Pt}-\mathrm{H}} \sim 28 \mathrm{~Hz}\right), 2.79\left(\mathrm{dd}, J=12.0,2.5 \mathrm{~Hz}, 1 \mathrm{H}, J_{\mathrm{Pt}-\mathrm{H}} \sim 65 \mathrm{~Hz}\right), 0.71(\mathrm{t}$, $J=7 \mathrm{~Hz}, 3 \mathrm{H})$. Selected data for the minor diastereomer 17a: ${ }^{1} \mathrm{H} \mathrm{NMR}\left(500 \mathrm{MHz}, \mathrm{CF}_{3} \mathrm{CD}_{2} \mathrm{OD}\right) \delta 4.28(t, J=7$ $\mathrm{Hz}, 1 \mathrm{H}), 3.32$ (dt, $\left.J=19.5 \mathrm{~Hz}, 7 \mathrm{H}, 2 \mathrm{H}, J_{\mathrm{Pt}-\mathrm{H}} \sim 81 \mathrm{~Hz}\right), 0.37$ (d, $\left.J=6 \mathrm{~Hz}, 6 \mathrm{H}\right)$. IR (KBr pellet) 2961, 2871, 2587, 1595, 1466, 1061, $522 \mathrm{~cm}^{-1}$; UV-Vis $\left(\mathrm{CF}_{3} \mathrm{CH}_{2} \mathrm{OH}\right) 200 \mathrm{~nm}\left(\varepsilon=7.70 \times 10^{4} \mathrm{M}^{-1} \cdot \mathrm{cm}^{-1}\right), 219 \mathrm{~nm}(\varepsilon=4.68 \times$ $\left.10^{4} \mathrm{M}^{-1} \cdot \mathrm{cm}^{-1}\right), 274 \mathrm{~nm}\left(\varepsilon=9.77 \times 10^{3} \mathrm{M}^{-1} \cdot \mathrm{cm}^{-1}\right), 381 \mathrm{~nm}\left(\varepsilon=6.70 \times 10^{3} \mathrm{M}^{-1} \cdot \mathrm{cm}^{-1}\right)$. HRMS (FAB +$) \mathrm{m} / z \mathrm{calcd}$ for $\mathrm{C}_{37} \mathrm{H}_{57} \mathrm{~N}_{2} \mathrm{Pt}^{+}\left[\mathrm{M}-\left\{\mathrm{CF}_{3} \mathrm{CD}_{2} \mathrm{OBF}_{3}\right\}\right]^{+} 724.4170$, found 724.4148 .

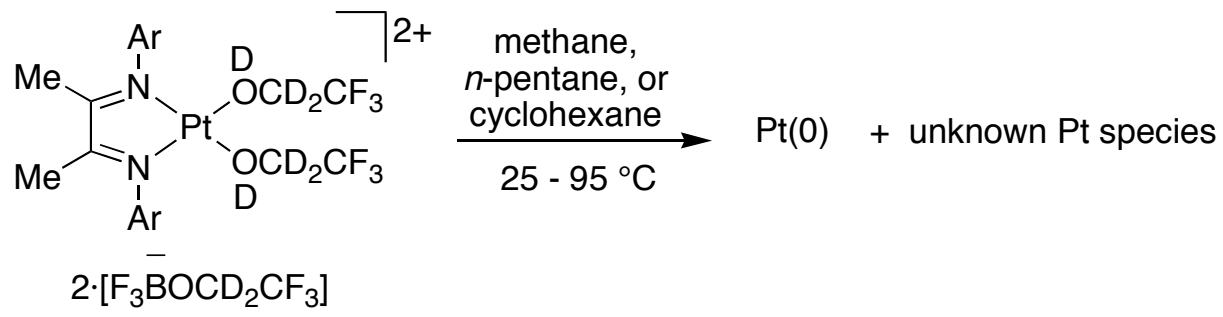

$5 \mathrm{a} \mathrm{Ar}=3,5-\mathrm{t}-\mathrm{Bu}_{2} \mathrm{C}_{6} \mathrm{H}_{3}$

Attempted $\mathbf{C}-\mathbf{H}$ bond activation of cyclohexane and $\boldsymbol{n}$-pentane. To $0.700 \mathrm{~mL}$ of a $0.015 \mathrm{M}$ solution of platinum dication 5a in trifluoroethanol- $d_{3}$ was added $0.011 \mathrm{~mL}$ of cyclohexane. [The solution of 5a was prepared by suspending $0.021 \mathrm{~g}$ of platinum dimethyl $1 \mathrm{a}(0.031 \mathrm{mmol})$ in $2.0 \mathrm{~mL}$ of trifluoroethanol- $d_{3}$. To the resulting purple heterogeneous mixture was added $0.175 \mathrm{~mL}$ of a $0.477 \mathrm{M}$ solution of $\mathrm{BF}_{3}$ in trifluoroethanol$d_{3}$. After brief agitation the mixture became a light orange solution. After $13 \mathrm{~h}$, the orange solution had faded to light yellow.] The reaction progress (or lack thereof) was analyzed periodically using ${ }^{1} \mathrm{H}$ NMR spectroscopy. 
The resulting yellow solution was heated to $50{ }^{\circ} \mathrm{C}$. After $20 \mathrm{~h}$, the reaction mixture was cooled to room temperature and was analyzed using ${ }^{1} \mathrm{H}$ NMR spectroscopy: no H/D isotope exchange was visible in the cyclohexane peak at $1.47 \mathrm{ppm}$ and little consumption of $\mathbf{5 a}$ had occurred. The reaction mixture was heated to $95{ }^{\circ} \mathrm{C}$. After $30 \mathrm{~h}$, the reaction mixture was cooled and analyzed using ${ }^{1} \mathrm{H}$ NMR spectroscopy: no H/D exchange in cyclohexane was apparent. $80 \%$ of platinum dication 5a had been consumed. Several new platinum species were visible (Diagnostic methyl singlets at $\left({ }^{1} \mathrm{H}\right.$ NMR $300 \mathrm{MHz}, \mathrm{CF}_{3} \mathrm{CD}_{2} \mathrm{OD} \delta 1.91,1.88$, and $1.83 \mathrm{ppm}$ ). Analysis of the reaction mixture using LRMS (ESI, methanol) revealed a major mass fragment at $685 \mathrm{~m} / \mathrm{z}$ and a minor fragment at $1357 \mathrm{~m} / \mathrm{z}$. These same platinum species were formed when the platinum dication $\mathbf{5 a}$ was heated to $95{ }^{\circ} \mathrm{C}$ for $30 \mathrm{~h}$ in the absence of substrate. The same procedure was followed using $0.012 \mathrm{~mL}$ of $n$-pentane. Identical results were obtained: no apparent H/D isotope exchange and only decomposition of the platinum complex was obtained.

Attempted $\mathbf{C}-\mathbf{H}$ bond activation of methane. To a purple suspension of platinum dimethyl $1 \mathbf{a}(0.022 \mathrm{~g}, 0.032$ $\mathrm{mmol}$ ) in $2.0 \mathrm{~mL}$ of trifluoroethanol- $d_{3}$ was added $0.150 \mathrm{~mL}$ of a $0.477 \mathrm{M}$ solution of $\mathrm{BF}_{3}$ in trifluoroethanol- $d_{3}$. After brief agitation, the heterogeneous mixture became a light orange solution. After $19 \mathrm{~h}, 0.500 \mathrm{~mL}$ of the resulting $0.014 \mathrm{M}$ solution of platinum dication 5a was placed in a specially designed high-pressure single crystal sapphire NMR tube. ${ }^{6}$ The resulting mixture was pressured with 475 psi of methane (1.86 mmol). The reaction progress (or lack thereof) was analyzed periodically using ${ }^{1} \mathrm{H}$ NMR spectroscopy. The resulting yellow solution was heated to $50{ }^{\circ} \mathrm{C}$. After $20 \mathrm{~h}$, the reaction mixture was cooled to room temperature and was analyzed using ${ }^{1} \mathrm{H}$ NMR spectroscopy: no H/D isotope exchange was visible in the methane peak at $0.17 \mathrm{ppm}$ and little consumption of $\mathbf{5 a}$ had occurred. The reaction mixture was heated to $95{ }^{\circ} \mathrm{C}$. After $30 \mathrm{~h}$, the reaction mixture was cooled and analyzed using ${ }^{1} \mathrm{H}$ NMR spectroscopy: no H/D exchange in methane was apparent. $80 \%$ of platinum dication $\mathbf{5 a}$ had been consumed. As before, several new platinum species were visible (Diagnostic methyl singlets at ( ${ }^{1} \mathrm{H}$ NMR $300 \mathrm{MHz}, \mathrm{CF}_{3} \mathrm{CD}_{2} \mathrm{OD} \delta 1.91,1.88$, and $1.83 \mathrm{ppm}$ ).

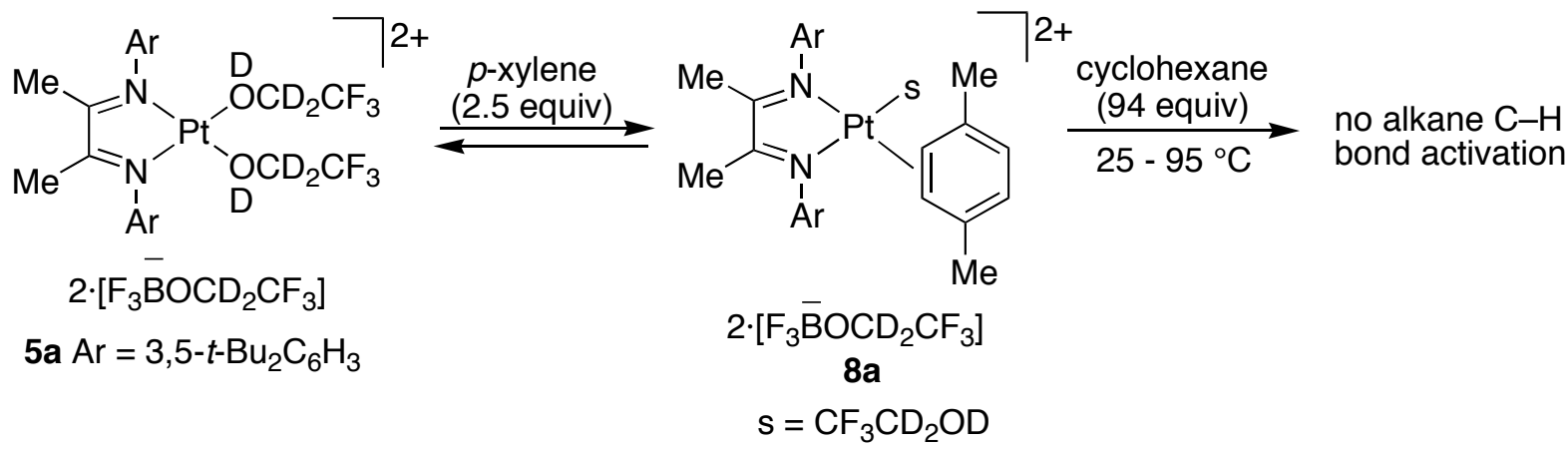

Attempted $\mathbf{C}-\mathbf{H}$ bond activation of cyclohexane using $\boldsymbol{\pi}$-arene 8a. To a $0.700 \mathrm{~mL}$ of a $0.014 \mathrm{M}$ solution of platinum dication 5a in trifluoroethanol- $d_{3}$ was added $0.0050 \mathrm{~mL}$ of $p$-xylene $(0.041 \mathrm{mmol})$. [The solution of 5a was prepared by suspending $0.021 \mathrm{~g}$ of platinum dimethyl $1 \mathrm{a}(0.031 \mathrm{mmol})$ in $2.05 \mathrm{~mL}$ of trifluoroethanol- $d_{3}$. To the resulting purple heterogeneous mixture was added $0.175 \mathrm{~mL}$ of a $0.477 \mathrm{M}$ solution of $\mathrm{BF}_{3}$ in trifluoroethanol- $d_{3}$. After brief agitation the mixture became a light orange solution. After $13 \mathrm{~h}$, the orange solution had faded to light yellow.] The reaction progress (or lack thereof) was analyzed periodically using ${ }^{1} \mathrm{H}$ NMR spectroscopy. Initial analysis of the reaction revealed a 33:66 mixture of $\pi$-arene 8a and dication 5a. The mixture was saturated by adding $0.080 \mathrm{~mL}$ of cyclohexane $(0.740 \mathrm{mmol})$. Analysis of the resulting mixture using ${ }^{1} \mathrm{H}$ NMR spectroscopy revealed no apparent change in the ration of $\mathbf{8 a}$ and $\mathbf{5 a}$. The reaction mixture was heated to $50{ }^{\circ} \mathrm{C}$. After $24 \mathrm{~h}$, analysis using ${ }^{1} \mathrm{H}$ NMR spectroscopy revealed that the residual hydroxyl peak of solvent had increased by a factor of six. The integration of the peaks associated with $p$-xylene was diminished, whereas the cyclohexane peak $(1.47 \mathrm{ppm})$ remained unchanged. The reaction mixture was heated to $95{ }^{\circ} \mathrm{C}$. 
After 8 h, analysis using ${ }^{1} \mathrm{H}$ NMR spectroscopy revealed that both $\mathbf{5 a}$ and $\mathbf{8 a}$ were consumed to form a variety of new complexes. As before, the integration of the cyclohexane peak was unchanged.

\section{References}

(1) Brown, H. C.; Johannesen, R. B. J. Am. Chem. Soc. 1953, 75, 16-20.

(2) Heyduk, A. F.; Labinger, J. A.; Bercaw, J. E. J. Am. Chem. Soc. 2003, 125, 6366-6367.

(3) Zhong, H. A.; Labinger, J. A.; Bercaw, J. E. J. Am. Chem. Soc. 2002, 124, 1378-1399.

(4) Heyduk, A. F.; Driver, T. G.; Labinger, J. A.; Bercaw, J. E. J. Am. Chem. Soc. 2004, 126, 15034-15035.

(5) Driver, T. G.; Day, M. W.; Labinger, J. A.; Bercaw, J. E. Organometallics 2005, 24, 3644-3654.

(6) For a detailed description and application of the specially designed high pressure NMR apparatus, see: Owen, J. S.; Labinger, J. A.; Bercaw, J. E. J. Am. Chem. Soc. 2006, 128, 2005-2016. 
VIII. Crystallographic data of $\mathbf{1 4 a}$

\section{$\underline{\text { Contents }}$}

Table 1. Crystal data

Figures Minimum overlap, unit cell contents, stereo view of unit cell contents

Table 2. Atomic Coordinates

Table 3. Selected bond distances and angles

Table 4.Full bond distances and angles

Table 5.Anisotropic displacement parameters

Table 6.Observed and calculated structure factors (available upon request)

Crystallographic data have been deposited at the CCDC, 12 Union Road, Cambridge CB2 1EZ, UK and copies can be obtained on request, free of charge, by quoting the publication citation and the deposition number 614486.

\section{Table 1. Crystal data and structure refinement}

Empirical formula

Formula weight

Crystallization Solvent

Crystal Habit

Crystal size

Crystal color

Type of diffractometer

Wavelength

Data Collection Temperature

$\theta$ range for 31422 reflections used

in lattice determination

Unit cell dimensions

Volume

Z

Crystal system

Space group

Density (calculated)

$\mathrm{F}(000)$

Data collection program

$\theta$ range for data collection
$\left[\mathrm{C}_{41} \mathrm{H}_{57} \mathrm{~N}_{2} \mathrm{Pt}\right]^{+}\left[\mathrm{BF}_{4}\right]^{-} \cdot \mathrm{CH}_{2} \mathrm{Cl}_{2}$

944.71

Dichloromethane/hexanes

Block

$0.31 \times 0.26 \times 0.17 \mathrm{~mm}^{3}$

Orange

\section{Data Collection}

Bruker SMART 1000

$0.71073 \AA$ MoK $\alpha$

100(2) K

2.49 to $38.30^{\circ}$

$\mathrm{a}=16.2295(4) \AA$

$\mathrm{b}=14.5556(3) \AA$

$\mathrm{c}=20.1968(5) \AA$

$\beta=113.1340(10)^{\circ}$

4387.44(18) $\AA^{3}$

4

Monoclinic

$\mathrm{P} 2{ }_{1} / \mathrm{c}$

$1.430 \mathrm{Mg} / \mathrm{m}^{3}$

1912

Bruker SMART v5.630

1.78 to $42.85^{\circ}$ 
Completeness to $\theta=42.85^{\circ}$

Index ranges

Data collection scan type

Data reduction program

Reflections collected

Independent reflections

Absorption coefficient

Absorption correction

Max. and min. transmission

Structure solution program

Primary solution method

Secondary solution method

Hydrogen placement

Structure refinement program

Refinement method

Data / restraints / parameters

Treatment of hydrogen atoms

Goodness-of-fit on $\mathrm{F}^{2}$

Final $\mathrm{R}$ indices [I $>2 \sigma(\mathrm{I}), 14960$ reflections]

$\mathrm{R}$ indices (all data)

Type of weighting scheme used

Weighting scheme used

Max shift/error

Average shift/error

Largest diff. peak and hole
$93.9 \%$

$-29 \leq \mathrm{h} \leq 28,-27 \leq \mathrm{k} \leq 26,-38 \leq 1 \leq 38$

$\omega$ scans at $7 \phi$ settings

Bruker SAINT v6.45A

121404

$30232\left[\mathrm{R}_{\mathrm{int}}=0.0637\right]$

$3.367 \mathrm{~mm}^{-1}$

SADABS

1.000000 and 0.911896

\section{Structure solution and Refinement}

Bruker XS v6.12

Direct methods

Difference Fourier map

Geometric positions

Bruker XL v6.12

Full matrix least-squares on $\mathrm{F}^{2}$

30232 / 0 / 483

Riding

1.429

$\mathrm{R} 1=0.0428, w \mathrm{R} 2=0.0733$

$\mathrm{R} 1=0.1167, w \mathrm{R} 2=0.0842$

Sigma

$w=1 / \sigma^{2}\left(\mathrm{Fo}^{2}\right)$

0.003

0.000

5.713 and -2.940 e. $\AA^{-3}$

\section{Special Refinement Details}

All difference Fourier peak greater than one electron lie very close to the Pt and could not be completely accounted for by absorption corrections. They represent no chemically reasonable alternatives and therefore it is assumed they arise from "noise".

Refinement of $\mathrm{F}^{2}$ against ALL reflections. The weighted R-factor $(w \mathrm{R})$ and goodness of fit $(\mathrm{S})$ are based on $\mathrm{F}^{2}$, conventional $R$-factors (R) are based on F, with $F$ set to zero for negative $F^{2}$. The threshold expression of $F^{2}>2 \sigma\left(F^{2}\right)$ is used only for calculating $\mathrm{R}$-factors (gt) etc. and is not relevant to the choice of reflections for refinement. R-factors based on $\mathrm{F}^{2}$ are statistically about twice as large as those based on F, and R-factors based on ALL data will be even larger.

All esds (except the esd in the dihedral angle between two l.s. planes) are estimated using the full covariance matrix. The cell esds are taken into account individually in the estimation of esds in distances, angles and torsion angles; correlations between esds in cell parameters are only used when they are defined by crystal symmetry. An approximate (isotropic) treatment of cell esds is used for estimating esds involving 1.s. planes. 


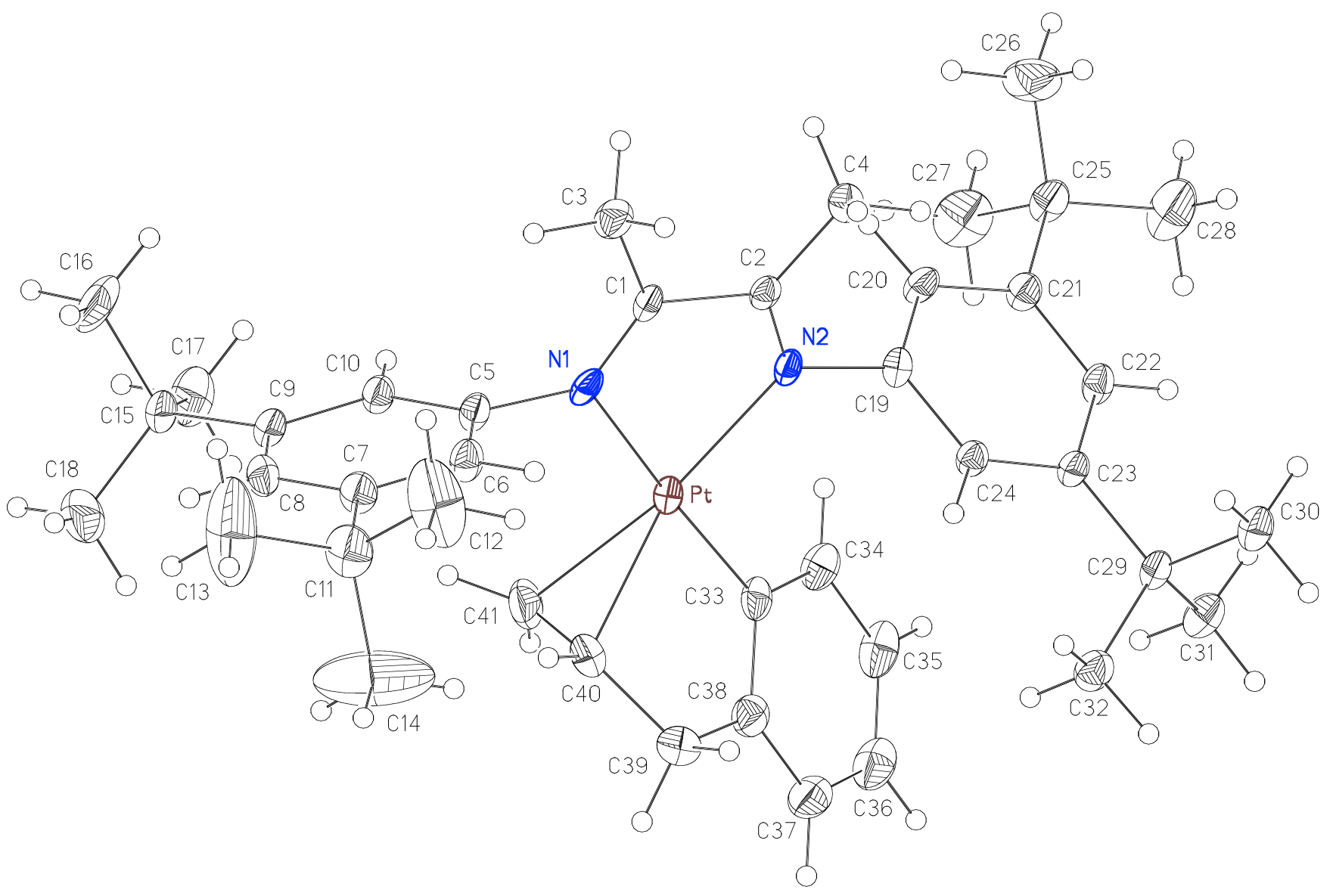




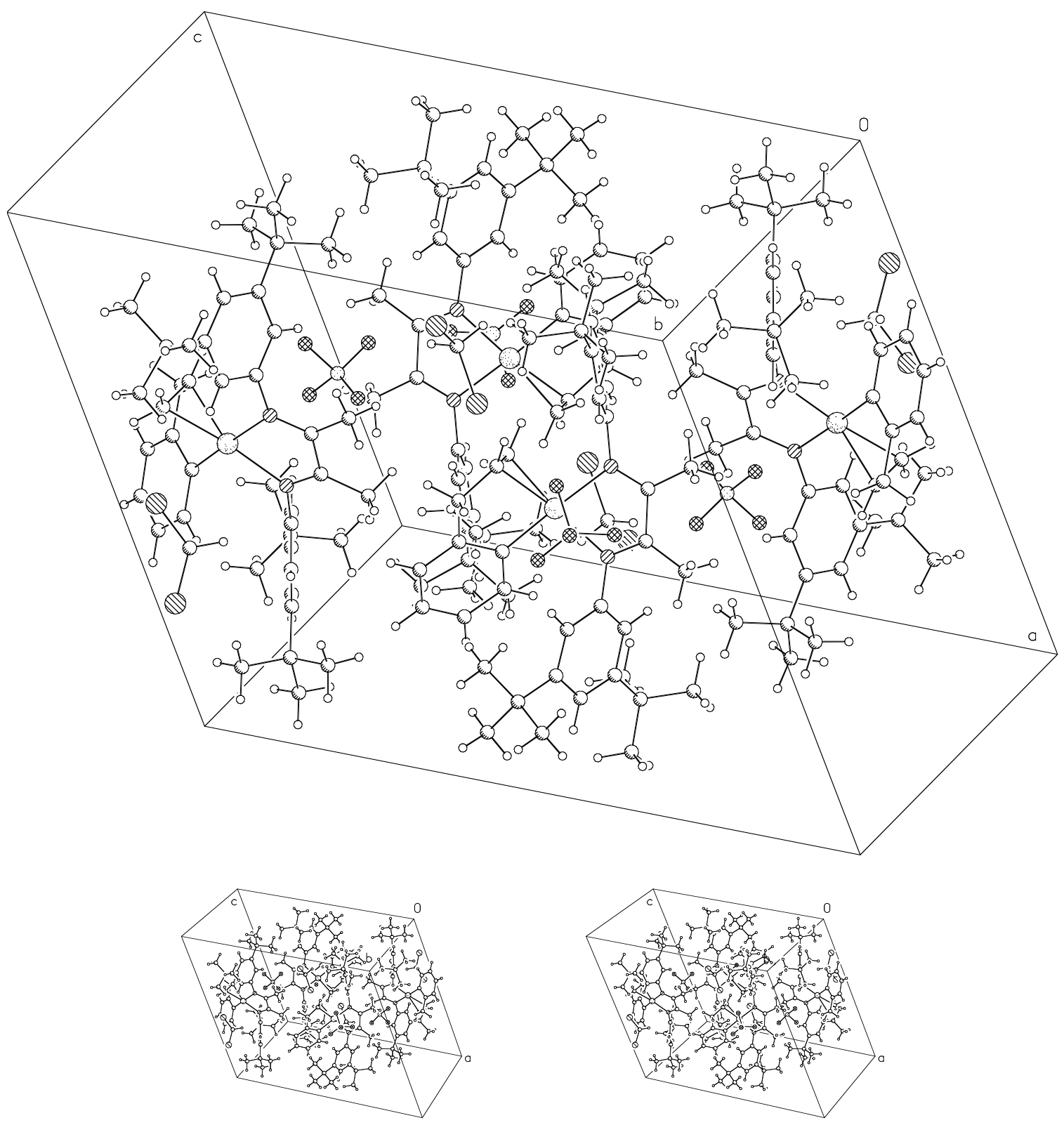


Table 2. Atomic coordinates $\left(x \mathbf{1 0}^{4}\right)$ and equivalent isotropic displacement parameters $\left(\AA^{2} \times 1^{3}\right)$. $U(e q)$ is defined as the trace of the orthogonalized $U^{\mathrm{ij}}$ tensor.

\begin{tabular}{|c|c|c|c|c|}
\hline & $\mathrm{x}$ & $\mathrm{y}$ & $\mathrm{z}$ & $\mathrm{U}_{\mathrm{eq}}$ \\
\hline $\mathrm{Pt}$ & $4776(1)$ & $2512(1)$ & 1033(1) & $16(1)$ \\
\hline $\mathrm{N}(1)$ & $5719(1)$ & $2166(1)$ & 2069(1) & $17(1)$ \\
\hline $\mathrm{N}(2)$ & $4057(1)$ & $2668(1)$ & $1669(1)$ & $16(1)$ \\
\hline $\mathrm{C}(1)$ & $5451(2)$ & $2273(1)$ & $2584(1)$ & $16(1)$ \\
\hline $\mathrm{C}(2)$ & 4491(1) & $2574(2)$ & $2352(1)$ & $15(1)$ \\
\hline $\mathrm{C}(3)$ & $6002(2)$ & $2134(2)$ & $3366(1)$ & $23(1)$ \\
\hline$C(4)$ & $4127(2)$ & $2768(2)$ & $2906(1)$ & $21(1)$ \\
\hline$C(5)$ & $6631(2)$ & $1925(2)$ & 2204(1) & $18(1)$ \\
\hline$C(6)$ & $7299(2)$ & $2578(2)$ & $2489(1)$ & $21(1)$ \\
\hline$C(7)$ & $8178(2)$ & $2371(2)$ & $2574(1)$ & $23(1)$ \\
\hline $\mathrm{C}(8)$ & $8334(2)$ & $1504(2)$ & $2351(2)$ & $23(1)$ \\
\hline $\mathrm{C}(9)$ & $7666(2)$ & $843(2)$ & $2058(1)$ & $21(1)$ \\
\hline$C(10)$ & $6801(2)$ & $1063(2)$ & 1993(1) & $19(1)$ \\
\hline $\mathrm{C}(11)$ & $8918(2)$ & $3102(2)$ & $2860(2)$ & $33(1)$ \\
\hline$C(12)$ & $8790(2)$ & $3700(3)$ & $3426(3)$ & $64(1)$ \\
\hline $\mathrm{C}(13)$ & $9837(2)$ & $2665(3)$ & $3217(3)$ & $83(2)$ \\
\hline$C(14)$ & $8866(4)$ & $3715(4)$ & $2236(3)$ & $101(2)$ \\
\hline$C(15)$ & $7880(2)$ & $-98(2)$ & $1821(2)$ & $24(1)$ \\
\hline$C(16)$ & $8310(3)$ & $-712(2)$ & $2485(2)$ & $44(1)$ \\
\hline$C(17)$ & $7031(2)$ & $-573(2)$ & $1302(2)$ & $37(1)$ \\
\hline $\mathrm{C}(18)$ & $8512(2)$ & $7(2)$ & $1433(2)$ & $42(1)$ \\
\hline C(19) & $3134(2)$ & $2956(2)$ & $1375(1)$ & $17(1)$ \\
\hline$C(20)$ & $2468(2)$ & $2353(1)$ & $1354(1)$ & $19(1)$ \\
\hline $\mathrm{C}(21)$ & $1567(2)$ & $2615(2)$ & 1012(1) & $19(1)$ \\
\hline$C(22)$ & $1383(2)$ & $3485(2)$ & 694(1) & $19(1)$ \\
\hline $\mathrm{C}(23)$ & $2061(2)$ & $4100(2)$ & $708(1)$ & $17(1)$ \\
\hline $\mathrm{C}(24)$ & 2941(2) & $3822(2)$ & 1061(1) & $17(1)$ \\
\hline$C(25)$ & $825(2)$ & $1933(2)$ & $974(2)$ & $24(1)$ \\
\hline $\mathrm{C}(26)$ & $1018(2)$ & $1538(2)$ & $1725(2)$ & $38(1)$ \\
\hline $\mathrm{C}(27)$ & $826(2)$ & $1137(2)$ & $472(2)$ & $41(1)$ \\
\hline $\mathrm{C}(28)$ & $-100(2)$ & $2374(2)$ & $693(3)$ & $53(1)$ \\
\hline C(29) & $1829(2)$ & $5042(2)$ & $342(1)$ & $19(1)$ \\
\hline$C(30)$ & $1605(2)$ & $5703(2)$ & 844(1) & $24(1)$ \\
\hline $\mathrm{C}(31)$ & $1027(2)$ & $4974(2)$ & $-387(1)$ & $26(1)$ \\
\hline$C(32)$ & $2620(2)$ & $5436(2)$ & 193(2) & $25(1)$ \\
\hline$C(33)$ & $3864(2)$ & 2939(2) & $84(1)$ & $20(1)$ \\
\hline$C(34)$ & $2964(2)$ & 2691(2) & $-232(2)$ & $25(1)$ \\
\hline$C(35)$ & $2397(2)$ & $3053(2)$ & $-904(2)$ & $30(1)$ \\
\hline$C(36)$ & $2736(2)$ & $3670(2)$ & $-1254(2)$ & $33(1)$ \\
\hline$C(37)$ & $3630(2)$ & $3909(2)$ & $-954(2)$ & $30(1)$ \\
\hline $\mathrm{C}(38)$ & $4197(2)$ & $3543(2)$ & $-294(1)$ & $24(1)$ \\
\hline C(39) & $5179(2)$ & $3778(2)$ & $67(2)$ & $29(1)$ \\
\hline$C(40)$ & $5675(2)$ & $3011(2)$ & $565(2)$ & $28(1)$ \\
\hline$C(41)$ & $5497(2)$ & $2078(2)$ & $397(2)$ & $32(1)$ \\
\hline$C(51)$ & $6418(2)$ & $5215(2)$ & $4213(2)$ & $42(1)$ \\
\hline $\mathrm{Cl}(1)$ & $5452(1)$ & $4877(1)$ & $4329(1)$ & $42(1)$ \\
\hline $\mathrm{Cl}(2)$ & $7200(1)$ & $4329(1)$ & 4401(1) & $78(1)$ \\
\hline
\end{tabular}




\begin{tabular}{lllll}
$\mathrm{B}(1)$ & $5518(3)$ & $4880(2)$ & $2220(2)$ & $44(1)$ \\
$\mathrm{F}(1)$ & $6226(2)$ & $4439(2)$ & $2073(2)$ & $85(1)$ \\
$\mathrm{F}(2)$ & $5874(1)$ & $5706(1)$ & $2550(1)$ & $44(1)$ \\
$\mathrm{F}(3)$ & $5366(2)$ & $4301(2)$ & $2660(1)$ & $99(1)$ \\
$\mathrm{F}(4)$ & $4879(2)$ & $5021(2)$ & $1558(1)$ & $56(1)$ \\
\hline
\end{tabular}


Table 3. Selected bond lengths $[\AA]]$ and angles $\left[^{\circ}\right]$

\begin{tabular}{lrlr}
\hline Pt-C(33) & $2.006(2)$ & $\mathrm{C}(33)-\mathrm{Pt}-\mathrm{N}(2)$ & $100.09(9)$ \\
Pt-N(2) & $2.060(2)$ & $\mathrm{C}(33)-\mathrm{Pt}-\mathrm{N}(1)$ & $175.22(8)$ \\
Pt-N(1) & $\mathrm{N}(2)-\mathrm{Pt}-\mathrm{N}(1)$ & $77.03(8)$ \\
Pt-C(41) & $2.111(2)$ & $\mathrm{C}(33)-\mathrm{Pt}-\mathrm{C}(41)$ & $83.72(11)$ \\
Pt-C(40) & $2.145(3)$ & $\mathrm{N}(2)-\mathrm{Pt}-\mathrm{C}(41)$ & $169.16(10)$ \\
& $2.151(3)$ & $\mathrm{N}(1)-\mathrm{Pt}-\mathrm{C}(41)$ & $99.80(10)$ \\
& & $\mathrm{C}(33)-\mathrm{Pt}-\mathrm{C}(40)$ & $81.33(11)$ \\
& & $\mathrm{N}(2)-\mathrm{Pt}-\mathrm{C}(40)$ & $152.23(10)$ \\
& & $\mathrm{N}(1)-\mathrm{Pt}-\mathrm{C}(40)$ & $99.42(10)$ \\
& & $\mathrm{C}(41)-\mathrm{Pt}-\mathrm{C}(40)$ & $38.11(11)$
\end{tabular}


Table 4. Bond lengths $[\AA ̊]$ and angles $\left[^{\circ}\right]$

\begin{tabular}{|c|c|c|c|}
\hline $\mathrm{Pt}-\mathrm{C}(33)$ & $2.006(2)$ & $\mathrm{B}(1)-\mathrm{F}(3)$ & $1.316(4)$ \\
\hline $\mathrm{Pt}-\mathrm{N}(2)$ & $2.060(2)$ & $\mathrm{B}(1)-\mathrm{F}(4)$ & $1.347(4)$ \\
\hline Pt-N(1) & $2.111(2)$ & $\mathrm{B}(1)-\mathrm{F}(2)$ & $1.386(4)$ \\
\hline Pt-C(41) & $2.145(3)$ & $\mathrm{B}(1)-\mathrm{F}(1)$ & $1.445(5)$ \\
\hline Pt-C(40) & $2.151(3)$ & & \\
\hline $\mathrm{N}(1)-\mathrm{C}(1)$ & $1.285(3)$ & C(33)-Pt-N(2) & $100.09(9)$ \\
\hline $\mathrm{N}(1)-\mathrm{C}(5)$ & $1.440(3)$ & C(33)-Pt-N(1) & $175.22(8)$ \\
\hline $\mathrm{N}(2)-\mathrm{C}(2)$ & $1.287(3)$ & $\mathrm{N}(2)-\mathrm{Pt}-\mathrm{N}(1)$ & 77.03(8) \\
\hline $\mathrm{N}(2)-\mathrm{C}(19)$ & $1.440(3)$ & C(33)-Pt-C(41) & $83.72(11)$ \\
\hline C(1)-C(3) & $1.492(3)$ & N(2)-Pt-C(41) & $169.16(10)$ \\
\hline $\mathrm{C}(1)-\mathrm{C}(2)$ & $1.506(3)$ & N(1)-Pt-C(41) & $99.80(10)$ \\
\hline$C(2)-C(4)$ & $1.483(3)$ & C(33)-Pt-C(40) & $81.33(11)$ \\
\hline$C(5)-C(6)$ & $1.386(3)$ & $\mathrm{N}(2)-\mathrm{Pt}-\mathrm{C}(40)$ & $152.23(10)$ \\
\hline$C(5)-C(10)$ & $1.386(3)$ & N(1)-Pt-C(40) & 99.42(10) \\
\hline$C(6)-C(7)$ & $1.401(3)$ & C(41)-Pt-C(40) & $38.11(11)$ \\
\hline$C(7)-C(8)$ & $1.396(3)$ & $\mathrm{C}(1)-\mathrm{N}(1)-\mathrm{C}(5)$ & $121.7(2)$ \\
\hline$C(7)-C(11)$ & $1.537(4)$ & $\mathrm{C}(1)-\mathrm{N}(1)-\mathrm{Pt}$ & $115.51(16)$ \\
\hline $\mathrm{C}(8)-\mathrm{C}(9)$ & $1.395(4)$ & $\mathrm{C}(5)-\mathrm{N}(1)-\mathrm{Pt}$ & $122.43(16)$ \\
\hline$C(9)-C(10)$ & $1.396(3)$ & $\mathrm{C}(2)-\mathrm{N}(2)-\mathrm{C}(19)$ & $121.0(2)$ \\
\hline C(9)-C(15) & $1.535(3)$ & $\mathrm{C}(2)-\mathrm{N}(2)-\mathrm{Pt}$ & $116.83(16)$ \\
\hline $\mathrm{C}(11)-\mathrm{C}(13)$ & $1.519(5)$ & $\mathrm{C}(19)-\mathrm{N}(2)-\mathrm{Pt}$ & $121.86(15)$ \\
\hline $\mathrm{C}(11)-\mathrm{C}(14)$ & $1.519(5)$ & $\mathrm{N}(1)-\mathrm{C}(1)-\mathrm{C}(3)$ & 126.1(2) \\
\hline $\mathrm{C}(11)-\mathrm{C}(12)$ & $1.514(5)$ & $\mathrm{N}(1)-\mathrm{C}(1)-\mathrm{C}(2)$ & $114.9(2)$ \\
\hline$C(15)-C(18)$ & $1.524(4)$ & $C(3)-C(1)-C(2)$ & $119.0(2)$ \\
\hline$C(15)-C(17)$ & $1.530(4)$ & $\mathrm{N}(2)-\mathrm{C}(2)-\mathrm{C}(4)$ & $125.2(2)$ \\
\hline$C(15)-C(16)$ & $1.533(4)$ & $\mathrm{N}(2)-\mathrm{C}(2)-\mathrm{C}(1)$ & $115.4(2)$ \\
\hline$C(19)-C(20)$ & $1.379(3)$ & $C(4)-C(2)-C(1)$ & $119.4(2)$ \\
\hline$C(19)-C(24)$ & $1.391(3)$ & $C(6)-C(5)-C(10)$ & $122.1(2)$ \\
\hline$C(20)-C(21)$ & $1.403(3)$ & $\mathrm{C}(6)-\mathrm{C}(5)-\mathrm{N}(1)$ & $119.3(2)$ \\
\hline$C(21)-C(22)$ & $1.398(3)$ & $\mathrm{C}(10)-\mathrm{C}(5)-\mathrm{N}(1)$ & $118.4(2)$ \\
\hline$C(21)-C(25)$ & $1.540(3)$ & $C(5)-C(6)-C(7)$ & $119.7(2)$ \\
\hline$C(22)-C(23)$ & $1.409(3)$ & $\mathrm{C}(8)-\mathrm{C}(7)-\mathrm{C}(6)$ & $117.5(2)$ \\
\hline$C(23)-C(24)$ & $1.383(3)$ & $C(8)-C(7)-C(11)$ & $122.2(2)$ \\
\hline$C(23)-C(29)$ & $1.534(3)$ & $C(6)-C(7)-C(11)$ & $120.2(2)$ \\
\hline$C(25)-C(28)$ & $1.522(4)$ & $\mathrm{C}(9)-\mathrm{C}(8)-\mathrm{C}(7)$ & $123.4(2)$ \\
\hline$C(25)-C(26)$ & $1.536(4)$ & $C(8)-C(9)-C(10)$ & $117.9(2)$ \\
\hline$C(25)-C(27)$ & $1.538(4)$ & C(8)-C(9)-C(15) & $120.9(2)$ \\
\hline$C(29)-C(31)$ & $1.538(3)$ & $C(10)-C(9)-C(15)$ & $121.2(2)$ \\
\hline$C(29)-C(30)$ & $1.541(3)$ & $C(5)-C(10)-C(9)$ & $119.5(2)$ \\
\hline$C(29)-C(32)$ & $1.539(3)$ & $C(13)-C(11)-C(14)$ & $111.3(4)$ \\
\hline$C(33)-C(34)$ & $1.393(4)$ & $\mathrm{C}(13)-\mathrm{C}(11)-\mathrm{C}(12)$ & $106.4(3)$ \\
\hline$C(33)-C(38)$ & $1.403(4)$ & $C(14)-C(11)-C(12)$ & $108.0(4)$ \\
\hline$C(34)-C(35)$ & $1.409(4)$ & $C(13)-C(11)-C(7)$ & $111.4(3)$ \\
\hline$C(35)-C(36)$ & $1.385(4)$ & $C(14)-C(11)-C(7)$ & $108.3(3)$ \\
\hline$C(36)-C(37)$ & $1.379(4)$ & $\mathrm{C}(12)-\mathrm{C}(11)-\mathrm{C}(7)$ & $111.3(3)$ \\
\hline $\mathrm{C}(37)-\mathrm{C}(38)$ & $1.395(4)$ & $C(18)-C(15)-C(17)$ & $107.4(3)$ \\
\hline C(38)-C(39) & $1.509(4)$ & $C(18)-C(15)-C(16)$ & $109.9(3)$ \\
\hline C(39)-C(40) & $1.506(4)$ & $C(17)-C(15)-C(16)$ & $108.3(3)$ \\
\hline $\mathrm{C}(40)-\mathrm{C}(41)$ & $1.402(4)$ & $\mathrm{C}(18)-\mathrm{C}(15)-\mathrm{C}(9)$ & $110.6(2)$ \\
\hline $\mathrm{C}(51)-\mathrm{Cl}(1)$ & $1.743(3)$ & $C(17)-C(15)-C(9)$ & $111.4(2)$ \\
\hline $\mathrm{C}(51)-\mathrm{Cl}(2)$ & $1.744(4)$ & $\mathrm{C}(16)-\mathrm{C}(15)-\mathrm{C}(9)$ & $109.2(2)$ \\
\hline
\end{tabular}




$\begin{array}{lc}\mathrm{C}(20)-\mathrm{C}(19)-\mathrm{C}(24) & 122.0(2) \\ \mathrm{C}(20)-\mathrm{C}(19)-\mathrm{N}(2) & 120.2(2) \\ \mathrm{C}(24)-\mathrm{C}(19)-\mathrm{N}(2) & 117.6(2) \\ \mathrm{C}(19)-\mathrm{C}(20)-\mathrm{C}(21) & 119.6(2) \\ \mathrm{C}(22)-\mathrm{C}(21)-\mathrm{C}(20) & 117.8(2) \\ \mathrm{C}(22)-\mathrm{C}(21)-\mathrm{C}(25) & 122.6(2) \\ \mathrm{C}(20)-\mathrm{C}(21)-\mathrm{C}(25) & 119.6(2) \\ \mathrm{C}(21)-\mathrm{C}(22)-\mathrm{C}(23) & 122.8(2) \\ \mathrm{C}(24)-\mathrm{C}(23)-\mathrm{C}(22) & 117.7(2) \\ \mathrm{C}(24)-\mathrm{C}(23)-\mathrm{C}(29) & 121.2(2) \\ \mathrm{C}(22)-\mathrm{C}(23)-\mathrm{C}(29) & 121.1(2) \\ \mathrm{C}(23)-\mathrm{C}(24)-\mathrm{C}(19) & 120.1(2) \\ \mathrm{C}(28)-\mathrm{C}(25)-\mathrm{C}(26) & 108.3(3) \\ \mathrm{C}(28)-\mathrm{C}(25)-\mathrm{C}(27) & 109.1(3) \\ \mathrm{C}(26)-\mathrm{C}(25)-\mathrm{C}(27) & 108.5(2) \\ \mathrm{C}(28)-\mathrm{C}(25)-\mathrm{C}(21) & 112.6(2) \\ \mathrm{C}(26)-\mathrm{C}(25)-\mathrm{C}(21) & 109.8(2) \\ \mathrm{C}(27)-\mathrm{C}(25)-\mathrm{C}(21) & 108.4(2) \\ \mathrm{C}(31)-\mathrm{C}(29)-\mathrm{C}(23) & 111.0(2) \\ \mathrm{C}(31)-\mathrm{C}(29)-\mathrm{C}(30) & 109.9(2) \\ \mathrm{C}(23)-\mathrm{C}(29)-\mathrm{C}(30) & 108.5(2) \\ \mathrm{C}(31)-\mathrm{C}(29)-\mathrm{C}(32) & 107.2(2) \\ \mathrm{C}(23)-\mathrm{C}(29)-\mathrm{C}(32) & 111.2(2) \\ \mathrm{C}(30)-\mathrm{C}(29)-\mathrm{C}(32) & 109.1(2) \\ \mathrm{C}(34)-\mathrm{C}(33)-\mathrm{C}(38) & 118.2(2) \\ \mathrm{C}(34)-\mathrm{C}(33)-\mathrm{Pt} & 127.2(2) \\ \mathrm{C}(38)-\mathrm{C}(33)-\mathrm{Pt} & 114.60(19) \\ \mathrm{C}(33)-\mathrm{C}(34)-\mathrm{C}(35) & 120.9(3) \\ \mathrm{C}(36)-\mathrm{C}(35)-\mathrm{C}(34) & 119.6(3) \\ \mathrm{C}(37)-\mathrm{C}(36)-\mathrm{C}(35) & 120.0(3) \\ \mathrm{C}(36)-\mathrm{C}(37)-\mathrm{C}(38) & 120.6(3) \\ \mathrm{C}(37)-\mathrm{C}(38)-\mathrm{C}(33) & 120.6(3) \\ \mathrm{C}(37)-\mathrm{C}(38)-\mathrm{C}(39) & 123.4(3) \\ \mathrm{C}(33)-\mathrm{C}(38)-\mathrm{C}(39) & 116.0(2) \\ \mathrm{C}(38)-\mathrm{C}(39)-\mathrm{C}(40) & 109.9(2) \\ \mathrm{C}(41)-\mathrm{C}(40)-\mathrm{C}(39) & 123.4(3) \\ \mathrm{C}(41)-\mathrm{C}(40)-\mathrm{Pt} & 70.70(19) \\ \mathrm{C}(39)-\mathrm{C}(40)-\mathrm{Pt} & 71.18(18) \\ \mathrm{C}(40)-\mathrm{C}(41)-\mathrm{Pt} & 112.21(19) \\ \mathrm{Cl}(1)-\mathrm{C}(51)-\mathrm{Cl}(2) & 119.4(4) \\ \mathrm{F}(3)-\mathrm{B}(1)-\mathrm{F}(4) & 112.7(3) \\ \mathrm{F}(3)-\mathrm{B}(1)-\mathrm{F}(2) & 111.0(3) \\ \mathrm{F}(4)-\mathrm{B}(1)-\mathrm{F}(2) & 103.3(3) \\ \mathrm{F}(3)-\mathrm{B}(1)-\mathrm{F}(1) & 103.1(3) \\ \mathrm{F}(4)-\mathrm{B}(1)-\mathrm{F}(1) & \\ \mathrm{F}(2)-\mathrm{B}(1)-\mathrm{F}(1) 105.6(3) & \end{array}$

$\mathrm{F}(2)-\mathrm{B}(1)-\mathrm{F}(1) 105.6(3)$ 
Table 5. Anisotropic displacement parameters $\left(\AA^{2} \times 10^{4}\right)$. The anisotropic displacement factor exponent takes the form: $-2 \pi^{2}\left[h^{2} a^{* 2} U^{11}+\ldots+2 h k a^{*} b^{*} U^{12}\right]$

\begin{tabular}{|c|c|c|c|c|c|c|}
\hline & $\mathrm{U}^{11}$ & $\mathrm{U}^{22}$ & $\mathrm{U}^{33}$ & $\mathrm{U}^{23}$ & $\mathrm{U}^{13}$ & $\mathrm{U}^{12}$ \\
\hline $\mathrm{Pt}$ & 147(1) & 144(1) & $185(1)$ & $-5(1)$ & $55(1)$ & 29(1) \\
\hline $\mathrm{N}(1)$ & 156(9) & $83(7)$ & $230(10)$ & $31(7)$ & $36(8)$ & $5(6)$ \\
\hline $\mathrm{N}(2)$ & $139(8)$ & 103(9) & 219(9) & $14(6)$ & $62(7)$ & $28(5)$ \\
\hline$C(1)$ & 141(10) & 113(9) & 214(11) & $22(7)$ & $42(8)$ & $24(6)$ \\
\hline$C(2)$ & $159(9)$ & $95(9)$ & 203(9) & $7(9)$ & $66(7)$ & $-1(8)$ \\
\hline$C(3)$ & $197(12)$ & $248(12)$ & $226(13)$ & $50(10)$ & $53(10)$ & 29(9) \\
\hline C(4) & 192(12) & $226(11)$ & $220(12)$ & $15(8)$ & $80(10)$ & $28(8)$ \\
\hline$C(5)$ & $142(10)$ & $148(10)$ & $232(12)$ & $16(8)$ & $55(9)$ & $23(7)$ \\
\hline$C(6)$ & 190(10) & 145(11) & 282(11) & $-26(10)$ & $85(8)$ & $4(9)$ \\
\hline$C(7)$ & $177(10)$ & 196(14) & 304(12) & $1(9)$ & 93(9) & $-16(8)$ \\
\hline$C(8)$ & 171(12) & $234(12)$ & 309(14) & $32(10)$ & $115(10)$ & $42(9)$ \\
\hline$C(9)$ & 233(12) & 167(11) & $238(12)$ & $30(9)$ & $99(10)$ & $61(8)$ \\
\hline$C(10)$ & 164(11) & $144(10)$ & 253(12) & $8(8)$ & $81(9)$ & $11(8)$ \\
\hline$C(11)$ & 199(13) & 299(15) & $460(18)$ & $-35(13)$ & 103(13) & $-79(10)$ \\
\hline$C(12)$ & $350(20)$ & $540(20)$ & $1000(40)$ & $-440(20)$ & $250(20)$ & $-200(17)$ \\
\hline$C(13)$ & 191(15) & $590(30)$ & $1480(50)$ & $-430(30)$ & $90(20)$ & $-60(16)$ \\
\hline$C(14)$ & $1110(50)$ & $1070(40)$ & $690(30)$ & $100(30)$ & $180(30)$ & $-830(40)$ \\
\hline$C(15)$ & 275(14) & 184(11) & 283(13) & $13(10)$ & $140(11)$ & 81(9) \\
\hline$C(16)$ & $690(30)$ & $235(15)$ & $374(18)$ & $63(13)$ & $187(17)$ & $253(15)$ \\
\hline$C(17)$ & 436(19) & 245(14) & 399(18) & $-98(12)$ & $132(15)$ & $60(12)$ \\
\hline$C(18)$ & $540(20)$ & $310(16)$ & $570(20)$ & $-27(15)$ & 382(19) & $80(14)$ \\
\hline$C(19)$ & $146(10)$ & 153(10) & 199(11) & $-14(8)$ & $47(9)$ & $27(7)$ \\
\hline$C(20)$ & 205(11) & $127(12)$ & 229(11) & $33(7)$ & $66(9)$ & 11(7) \\
\hline $\mathrm{C}(21)$ & 154(9) & 168(13) & $235(10)$ & $12(9)$ & $57(8)$ & $-4(8)$ \\
\hline$C(22)$ & 133(10) & $159(10)$ & $256(12)$ & $4(9)$ & $49(9)$ & $11(7)$ \\
\hline$C(23)$ & 170(11) & $127(9)$ & 190(11) & $2(8)$ & $61(9)$ & $13(7)$ \\
\hline$C(24)$ & $147(10)$ & 141(10) & 213(11) & $7(8)$ & $63(9)$ & $1(7)$ \\
\hline$C(25)$ & $158(11)$ & 186(11) & $345(15)$ & $48(10)$ & $58(10)$ & $-19(8)$ \\
\hline$C(26)$ & 331(17) & 364(17) & $457(19)$ & $75(14)$ & 171(15) & $-126(13)$ \\
\hline$C(27)$ & 373(18) & 311(16) & $500(20)$ & $-56(14)$ & $100(16)$ & $-133(13)$ \\
\hline$C(28)$ & 190(13) & $350(20)$ & $1000(30)$ & $229(19)$ & 197(16) & $-4(12)$ \\
\hline$C(29)$ & $165(11)$ & $147(10)$ & $224(12)$ & $18(8)$ & $52(9)$ & $29(8)$ \\
\hline $\mathrm{C}(30)$ & 248(13) & 172(11) & $290(14)$ & $-4(9)$ & 91(11) & $36(9)$ \\
\hline $\mathrm{C}(31)$ & $230(13)$ & $225(12)$ & 256(13) & $31(10)$ & $31(10)$ & 23(9) \\
\hline$C(32)$ & $227(13)$ & 188(12) & $327(15)$ & $38(10)$ & $106(11)$ & $0(9)$ \\
\hline $\mathrm{C}(33)$ & 211(12) & 186(11) & 195(12) & $-44(9)$ & $68(9)$ & $53(9)$ \\
\hline$C(34)$ & 248(13) & 192(13) & 251(12) & $-23(8)$ & $42(10)$ & $21(8)$ \\
\hline$C(35)$ & 279(14) & 283(14) & 251(14) & $-68(11)$ & 1(11) & $75(11)$ \\
\hline$C(36)$ & 390(17) & $330(15)$ & 196(13) & $-11(11)$ & $50(12)$ & $120(12)$ \\
\hline$C(37)$ & 442(18) & $260(14)$ & 201(13) & $12(10)$ & 141(12) & $81(12)$ \\
\hline$C(38)$ & 313(14) & $224(12)$ & 207(12) & $-11(9)$ & $114(11)$ & $63(10)$ \\
\hline$C(39)$ & $319(16)$ & $319(15)$ & 284(14) & $55(11)$ & $162(12)$ & $35(11)$ \\
\hline $\mathrm{C}(40)$ & 231(14) & $332(16)$ & $329(16)$ & $41(12)$ & $169(12)$ & $68(11)$ \\
\hline $\mathrm{C}(41)$ & $334(17)$ & $366(16)$ & 292(16) & $-5(13)$ & 172(14) & $148(13)$ \\
\hline$C(51)$ & $580(20)$ & $376(18)$ & $365(18)$ & $-76(14)$ & 241(17) & $-161(15)$ \\
\hline $\mathrm{Cl}(1)$ & $459(5)$ & 439(5) & 388(4) & $39(4)$ & 191(4) & $-4(4)$ \\
\hline $\mathrm{Cl}(2)$ & $429(6)$ & 849(9) & $986(10)$ & $-442(8)$ & $183(6)$ & $-11(5)$ \\
\hline
\end{tabular}




\begin{tabular}{lrllcrc}
$\mathrm{B}(1)$ & $720(30)$ & $180(15)$ & $340(20)$ & $-10(13)$ & $110(20)$ & $-52(16)$ \\
$\mathrm{F}(1)$ & $1000(20)$ & $609(17)$ & $960(20)$ & $165(15)$ & $407(18)$ & $457(16)$ \\
$\mathrm{F}(2)$ & $742(15)$ & $164(8)$ & $412(11)$ & $-43(7)$ & $233(10)$ & $-123(8)$ \\
$\mathrm{F}(3)$ & $1990(30)$ & $565(15)$ & $463(14)$ & $-174(12)$ & $543(18)$ & $-832(19)$ \\
$\mathrm{F}(4)$ & $440(13)$ & $704(16)$ & $467(13)$ & $65(11)$ & $98(10)$ & $-186(11)$ \\
\hline
\end{tabular}

